PAULO ALEXANDRE DE CARVALHO MORAES

\title{
A REGULAÇÃO DA EXPRESSÃO GÊNICA DO GLUT4 INDUZIDA PELO JEJUM E INSULINA EM MÚSCULO SÓLEO DE RATOS E A PARTICIPAÇÃO DO FATOR TRANSCRICIONAL NUCLEAR
} FACTOR-KAPPA B (NF-KB)

Dissertação apresentada ao Instituto de Ciências Biomédicas da Universidade de São Paulo, para obtenção do Título de Mestre em Ciências.

Área de concentração: Fisiologia

Orientador: Prof. Dr. Ubiratan Fabres Machado

São Paulo 


\section{RESUMO}

O objetivo dessa pesquisa foi investigar a regulação induzida pelo jejum in vivo e pela insulina in vitro sobre a expressão do GLUT4 no músculo sóleo de ratos, além da possível participação do fator transcricional Nuclear Factorkappa B (NF-kB) nesta regulação. Analisou-se o músculo sóleo de ratos Wistar obtidos no estado alimentado ad libitum ou submetidos a jejum de 48 horas. Além disso, músculos sóleos de ratos submetidos ao jejum de 48 horas foram removidos, fixados em suporte inoxidável e incubados por 70, 120 e 180 minutos em 25 ml de solução Krebs-Henseleit Buffer (KHB) em banhomaria a $37^{\circ} \mathrm{C}$, com fluxo de $95 \%$ de $\mathrm{O}_{2}$ e $5 \%$ de $\mathrm{CO}_{2}$ e pH em 7,4, adicionado ou não com 16,7 nM de insulina regular. A expressão do GLUT4 foi avaliada pela análise dos conteúdos de mRNA (Northern blotting) e proteína (Western

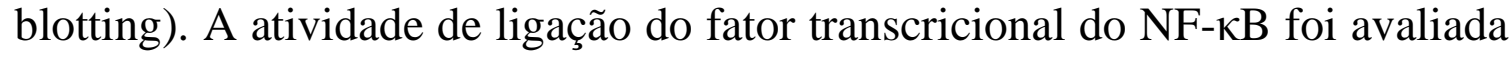
pela capacidade de ligação de proteínas nucleares ao sítio de ligação do NF$\kappa \mathrm{B}$ ao DNA (Electroforetic Mobility Shift Assay - EMSA), ensaio de mobilidade eletroforética. Ratos jejuados por 48 horas apresentaram diminuição no mRNA de GLUT4 em 24\% (p<0,05), aumento na atividade de

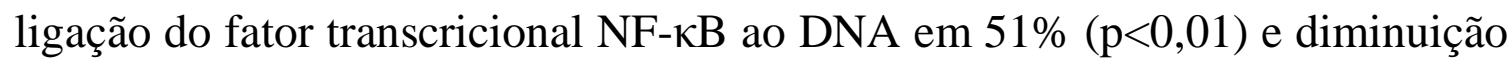
no conteúdo protéico total em $30 \%(\mathrm{p}<0,01)$ no músculo sóleo quando 
comparado ao grupo alimentado. Comparando-se o músculo dos ratos jejuados e jejuados com músculo submetido à incubação por 70 minutos em solução KHB, verificou-se um aumento de $38 \%(\mathrm{p}<0,05)$ na expressão do mRNA do

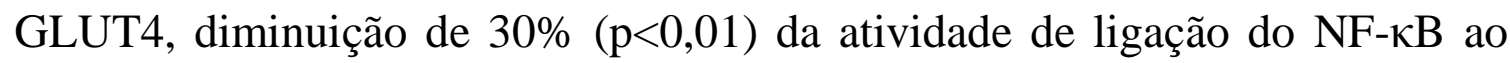
DNA e manutenção nos níveis do conteúdo protéico total de GLUT4 . A incubação com insulina $(16,7 \mathrm{nM})$ por 70 minutos do músculo sóleo de ratos jejuados aumentou o mRNA de GLUT4 em 37\% ( $<<0,05)$, diminuiu a atividade de ligação do NF- $\kappa$ B ao DNA em $30 \%(\mathrm{P}<0,05)$ e aumentou o conteúdo protéico total de GLUT4 em 33\% (p<0,05) em relação a incubação em solução KHB pura. A incubação por 120 e 180 minutos em solução KHB com insulina $(16,7 \mathrm{nM})$ do músculo sóleo de ratos jejuados por 48 horas intensificou a alteração causada pela incubação por 70 minutos, demonstrando um efeito tempo-dependente na expressão do mRNA do GLUT4 que aumentou $30 \%(\mathrm{p}<0,05)$ e $25 \%(\mathrm{p}<0,05)$, respectivamente. A atividade de

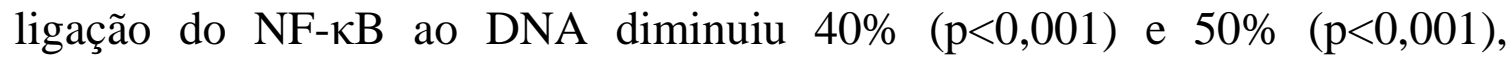
respectivamente e o conteúdo protéico total de GLUT4 aumentou 40\% $(\mathrm{p}<0,05)$ e $50 \%(\mathrm{p}<0,001)$, respectivamente. Esses resultados indicam que o jejum por 48 horas e a incubação tecidual "in vitro" com KHB acrescido de

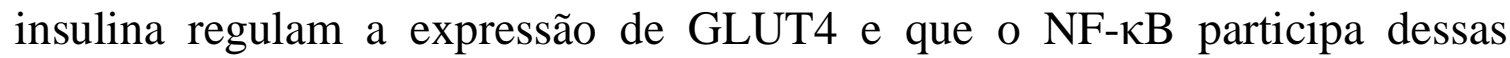
modulações. Palavras chave: Insulina. Jejum. GLUT4. NF-кB. Sóleo. 


\section{SUMMARY}

The aim of this research was to investigate the regulation induced by fasting in vivo and insulin in vitro of GLUT4 expression in soleus muscle of rats, beyond the possible participation of transcriptional factor Nuclear Factor -kappa B (NF- $\mathrm{kB})$ in this regulation. It was analized the soleus muscle of Wistar rats obtained in the fed state ad libitum or submitted to a 48 hours food deprivation. Besides, soleus muscle from fasted-rats were removed, fixed in stainless support and incubated for 70,120 and 180 minutes in $25 \mathrm{~mL}$ of Krebs-Henseilet Buffer (KHB) at $37{ }^{\circ} \mathrm{C}$, with flow of $95 \%-\mathrm{O}_{2}$ and $5 \%-\mathrm{CO}_{2}$, $\mathrm{pH}$ in 7,4, added or not with $16,7 \mathrm{nM}$ of regular insulin. After the incubation, the muscles were immediately frozen in liquid nitrogen for further analysis. The GLUT4 expression was evaluated by analysis of the mRNA contents (Northern blotting) and protein (Western blotting). The binding activity of the transcriptional factor NF- $\mathrm{KB}$ was evaluated by the capacity of binding of nuclear proteins to the binding sites of $\mathrm{NF}-\mathrm{\kappa B}$ to DNA (Electroforetic Mobility Shift Assay - EMSA). Fasted-rats presented a decrease in GLUT4 mRNA of $24 \%(\mathrm{p}<0,05)$, increase in binding activity of the transcriptional factor NF- $\mathrm{KB}$ to DNA in $51 \%(\mathrm{p}<0,01)$ and decrease in the total protein content in $30 \%(\mathrm{p}<0,05)$ in soleus muscle when compared with the fed-rats. 
Comparing the muscle of fasted-rats and fasted-rats with muscle submitted to the incubation for 70 minutes in $\mathrm{KHB}$, it was verified an increase of $38 \%$ $(\mathrm{p}<0,05)$ in the expression of GLUT4 mRNA, decrease of $30 \%(\mathrm{p}<0,01)$ in the binding activity of NF- $\mathrm{BB}$ to DNA and maintenance in the levels of total protein content of GLUT4. The incubation with insulin $(16,7 \mathrm{nM})$ for 70 minutes of the soleus muscle of fasted-rats increased the GLUT4 mRNA in $37 \%(\mathrm{p}<0,05)$, decreased the binding activity of NF- $\kappa \mathrm{B}$ to DNA in $30 \%$ $(\mathrm{p}<0,05)$ and increased the total protein content of GLUT4 in $33 \%(\mathrm{p}<0,05)$ in relation to incubation with pure KHB. The incubation for 120 and 180 minutes in KHB with insulin $(16,7 \mathrm{nM})$ of soleus muscle of fasted-rats by 48 hours intensified the alterations caused by the incubation for 70 minutes, demonstrating a time-dependent effect in the expression of GLUT4 mRNA wich increased $30 \%(\mathrm{p}<0,05)$ and $25 \%(\mathrm{p}<0,05)$, respectively. The binding activity of NF- $\kappa$ B to DNA decreased $40 \%(\mathrm{p}<0,001)$ and $50 \%(\mathrm{p}<0,001)$, respectively and the total protein content of GLUT4 increased $40 \%(\mathrm{p}<0,05)$ and $50 \%(\mathrm{p}<0,001)$, respectively. These results indicate that the fasting for 48 hours and the tissular incubation in vitro with KHB added of insulin regulate the GLUT4 expression and the NF- $\mathrm{kB}$ participates of these modulations. Key words: Insulin. Fasting. GLUT4. NF-кB. Soleus. 


\section{SUMÁRIO}

1. Introdução

1.1. Captação de glicose $\quad 7$

1.2. Expressão do GLUT4 11

1.3. Fator transcricional NF-kB 14

2. Objetivos 17

3. Materiais e métodos 18

3.1. Animais 18

3.2. Incubação dos tecidos 18

3.3.Quantificação do mRNA do GLUT4 19

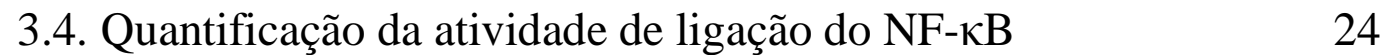

3.5. Quantificação da proteína GLUT4 27

3.6. Análise estatística dos resultados 30

4. Resultados 31

5. Discussão 45

6. Conclusões 55

7. Referência Bibliográfica 57 


\section{INTRODUÇÃO}

\subsection{Captação de glicose}

A glicose é a principal fonte energética do organismo e possui papel importante no metabolismo e homeostase celular. Muitas células são dependentes de um contínuo suprimento de glicose como fonte da geração de adenosina tri-fosfato (ATP), a "moeda energética" do organismo (GOULD \& HOLMANN, 1993).

A bicamada lipídica da membrana plasmática das células é impermeável a moléculas hidrofílicas como a glicose. Desta forma, o acesso da glicose as células não ocorre livremente, ele é dependente de proteínas transportadoras que deslocam a glicose tanto para dentro quanto para fora da célula. Existem dois tipos de transportadores de glicose, os transportadores de glicose dependentes de sódio (SGLT) e os facilitadores de transporte de glicose (GLUT) (SCHEEPERS et al., 2004).

A família GLUT é composta por 14 membros que são numerados pela ordem cronológica de seu descobrimento (SATO et al., 1996). São proteínas de 45-60 kDa com 12 -hélices transmembrânicas e hidrofóbicas, interligadas 
por alças hidrofílicas, distribuídas de forma que a porção C-terminal e a Nterminal fiquem do lado citoplasmático (JOOST et al., 2001).

Os GLUTs são expressos de forma tecido/célula-específicos, apresentando propriedades cinéticas e reguladoras distintas, que refletem seu papel no metabolismo celular da glicose e homeostase glicêmica (MACHADO et al., 2006).

O músculo esquelético é o maior território envolvido na captação de glicose no período pós-prandial, processo importante para manutenção de uma glicemia normal. A insulina estimula a captação de glicose e seu armazenamento na forma de glicogênio. Desta forma a captação de glicose pelo músculo esquelético proporciona a homeostase glicêmica e uma reserva energética para a célula. O transportador de glicose mais importante e abundante neste tecido é o GLUT4 (ZORZANO et al., 2000).

As fibras musculares diferem entre si em alguns aspectos como coloração do tecido (fibras vermelhas ou brancas), metabolismo (oxidativas ou glicolíticas), velocidade de contração e característica de inervação (contração rápida ou lenta). O GLUT4 é mais abundante em fibras vermelhas (oxidativas e de contração lenta) e fibras intermediárias (oxidativas-glicolíticas e de contração rápida), do que em fibras brancas (glicolíticas e de contração rápida) (GASTER et al., 2000). 
O tecido adiposo também participa da captação de glicose e seus produtos, tais como TNF- $\alpha$, IL-6, resistina e adiponectina influenciam diretamente na sensibilidade insulínica dos demais tecidos (MACHADO et al., 2006).

Em condições basais, o GLUT4 encontra-se em vesículas intracelulares e sob estímulo da insulina ou contração muscular é translocado para a membrana plasmática. Essa movimentação do GLUT4 permite agudamente um aumento da captação de glicose (CORTRIGHT et al., 1997).

A translocação do GLUT4 para membrana plasmática induzida agudamente pela insulina e pela contração muscular ocorre de forma diferente. A ação da insulina inicia-se com sua ligação a um receptor específico. O receptor de insulina é um receptor transmembrana com atividade tirosina cinase intrínseca. Possui duas subunidades $\alpha$ (extracelular) e duas subunidades $\beta$ (extracelular/transmembrana/intracelular). De maneira geral, a ligação da insulina à subunidade $\alpha$ resulta em alteração conformacional e autofosforilação de resíduos de tirosina da subunidade $\beta$, induzindo a atividade tirosina-cinase. Inicia-se então uma cascata de sinalização intracelular fosforilando uma série de proteínas citosólicas em tirosina. O estímulo insulínico resulta na fosforilação em tirosina das proteínas IRS, gerando sítios de reconhecimento SH2. A associação e ativação subseqüente 
da unidade regulatória de 85-kDA da fosfatidilinositol 3-cinase (PI3K) causa a fosforilação do substrato fosfatidilinositol 4,5 bifosfato (PIP2) para gerar fosfatidilinositol 3,4,5 trifosfato (PIP3), estágio essencial para translocação de GLUT4. A geração de PIP3 recruta a proteína cinase B (PKB) para membrana plasmática através de interações específicas com seu domínio $\mathrm{PH}$, onde é fosforilada em treonina e serina. A fosforilação da PKB está envolvida nos eventos que conduzem a translocação de vesículas ricas em transportadores GLUT4 do citosol para membrana plasmática, resultando num aumento da captação de glicose pela célula (WATSON et al., 2004).

Já a atividade contrátil atua por uma via independente da PI3K. Dois elementos são propostos para contribuir na captação de glicose, o AMP (adenosina monofosfato) resultado da degradação do ATP, e o $\mathrm{Ca}^{2+}$ liberado pelo retículo endoplasmático após despolarização da membrana do túbulo transverso (ZORZANO et al., 2005).

Os efeitos da insulina e da contração muscular na translocação do GLUT4 na musculatura esquelética são aditivos, sugerindo que além de utilizarem vias de sinalização intracelular distintas, existam compartimentos distintos de vesículas respondendo a cada tipo de estímulo (GAO et al., 1994). De fato, existem duas populações morfologicamente distintas de vesículas 
intracelulares de GLUT4 que são recrutadas diferencialmente pela insulina e contração muscular (PLOUG et al., 1998).

\subsection{Expressão do GLUT4}

Vários fatores fisiológicos ou farmacológicos podem influenciar a expressão do GLUT4. Por exemplo, mudanças em longo prazo na sensibilidade insulínica e atividade contrátil são capazes de induzir alterações na expressão do gene do GLUT4, modificando o conteúdo celular da proteína GLUT4, a quantidade translocada e conseqüentemente a captação de glicose. (SILVA et al., 2005).

O diabetes (GARVEY et al., 1989) e a desnervação (BLOCK et al., 1991) diminuem a expressão de GLUT4 na musculatura esquelética, já o treinamento com exercícios (PLOUG et al., 1990), o tratamento com hormônio tireoidiano (WEINSTEIN et al., 1991) e a elevação da concentração de $\mathrm{Ca}^{2+}$ intracelular (OJUKA et al., 2002) são capazes de aumentar a expressão de GLUT4. Tanto a insulina como a contração muscular ativam a via de sinalização da mitogen activated protein kinase (MAPK) (GOODYEAR et al., 1996), que está envolvida no controle da expressão gênica e síntese protéica de GLUT4 (HILL \& TREISMAN., 1995). 
A insulina atua na expressão do GLUT4 de forma tecido específica e, às vezes, variável no mesmo tecido de acordo com a situação. Em pesquisas com células musculares e adiposas em cultura, a insulina diminuiu a expressão de GLUT4 (KOIVISTO et al., 1991; FLORES-RIVEROS et al., 1993), mas em coração e músculo esquelético de animais diabéticos, a insulina aumentou a expressão de GLUT4 (MORA \& PESSIN, 2000).

A regulação da transcrição gênica do GLUT4 também pode ser influenciada pelo estado alimentar. Provavelmente, esse fato foi fundamental para evolução da espécie humana, pois o armazenamento de energia durante os períodos de abundância de alimento propiciou a sobrevivência durante os períodos de escassez. Os genes com essa característica são chamados de genes de poupança (NEEL, 1962). No entanto, esses mesmos genes que foram essenciais no passado, podem ter um efeito negativo hoje com o aumento da disponibilidade de alimento da vida moderna, provocando o aumento da obesidade e diabetes. Aparentemente o jejum prolongado (48 a 72 horas) atua na expressão do GLUT4, de forma tecido-específica, seja aumentando, seja diminuindo sua transcrição (CAMPS et al., 1992). Já a realimentação após jejum aumenta rapidamente a expressão do GLUT4 em músculo (ZANQUETTA et al.,2006). 
A transcrição do gene do GLUT4, assim como de outros genes é regulada por fatores transcricionais, que são proteínas que contribuem para estimular ou inibir a transcrição gênica. Os mais estudados ativadores da transcrição de GLUT4 são os MEFs2 (myocite enhancer factors 2) (MacLEAN et al., 2000) e o PPAR- $\gamma$ (peroxisomal proliferator activated receptor gama) (SHIMAYA et al., 1998). O TR $\alpha-1$ (thyroid hormone receptor alpha-1 -) (SANTALUCIA et al., 2001), MyoD (SANTALUCIA et al., 2001), NRF-1 (nuclear respiratory factor 1) (DOHM, 2002) e o KLF15 (Krüppellike factor 15) (GRAY et al., 2002) também são descritos como ativadores da transcrição de GLUT4. Além disso, é possível que o fator induzido pela hipóxia 1-a (hypoxia inducible factor 1-a - HIF1-a), um mediador da expressão dos genes do GLUT 1 e 3 (EBERT et al., 1996), também regule a expressão de GLUT4, pois a hipóxia por si é capaz de aumentar a expressão de GLUT4 (ROYER, 2000). De fato, estudos de nosso laboratório confirmaram o papel estimulador do HIF1-a sobre o gene do GLUT4 (SILVA et al.,2005).

Por outro lado, alguns fatores atuam na inibição do gene do GLUT4, como o fator nuclear-kappa $\mathrm{B}$, nuclear factor-kappa $B(\mathrm{NF}-\kappa \mathrm{B})$, um mediador dos efeitos de TNF- $\alpha$ (tumor-necrosis factor) (RUAN et al., 2002). 


\subsection{Fator transcricional NF- $\mathrm{KB}$}

O NF-kB é uma proteína dimérica, cujos monômeros pertencem à família das proteínas Rel/NF-кB. Essa família é constituída por cinco proteínas: p50, p52, p65 (RelA), RelB e c-Rel que formam vários dímeros sendo o heterodímero p50/RelA a forma mais comum (KUMAR et al., 2004). Elas apresentam um domínio comum chamado RHD (Rel-homology domain) que é responsável pela dimerização, ligação ao DNA e interação com a proteína inibitória IкB, assim como pela seqüência de localização nuclear (NLS). A proteína NF-kB está presente no citoplasma de forma inativa

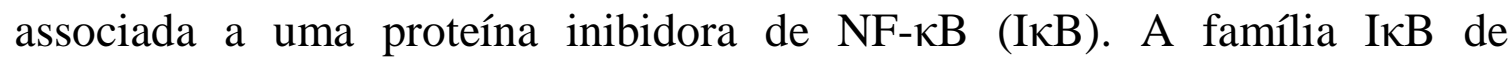
proteínas inclui $\mathrm{I} \kappa \mathrm{B} \alpha, \mathrm{I} \kappa \mathrm{B} \beta, \mathrm{I} \kappa \mathrm{B} \gamma, \mathrm{I} \kappa \mathrm{B} \varepsilon, \mathrm{Bcl}-3$ e as proteínas precursoras p105

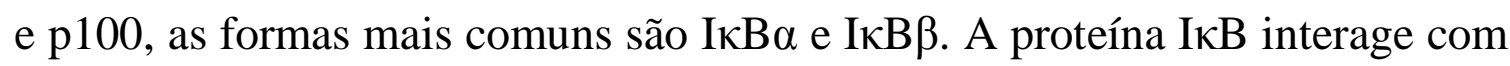
a seqüência de localização nuclear (NLS), localizada na porção amino-

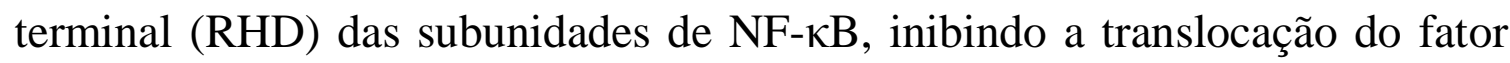
de transcrição do citoplasma para o núcleo e a ligação do NF-kB ao DNA de genes alvos (BALDWIN, 1996).

O NF- $\kappa$ B possui importante papel no controle do sistema imunológico e processos inflamatórios, sua ativação ocorre por vários estímulos como: exposição das células à LPS ou citocinas inflamatórias como TNF ou IL-1, 
infecção viral ou expressão de certos produtos gênicos virais, radiação UV, ativação celular B ou T e por outros estímulos fisiológicos e não fisiológicos (BALDWIN, 1996). Assim, após estímulo, o complexo IкB cinase (IKK) é ativado, fosforilando IкB. Essa fosforilação inicia seu processo de degradação,

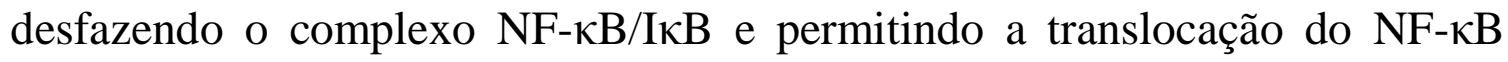
para o núcleo com subseqüente ligação em sítios específicos do DNA para regular a transcrição de um grande número de genes (LI \& VERMA, 2002).

Embora o efeito da insulina e da atividade contrátil na translocação do GLUT4 esteja bem definido, o efeito na sua transcrição ainda não está esclarecido. Estudos anteriores no laboratório demonstraram que no músculo sóleo de rato jejuado por 48 horas há diminuição do mRNA de GLUT4 e aumento no mRNA de NF-кB. Já no músculo sóleo incubado com insulina

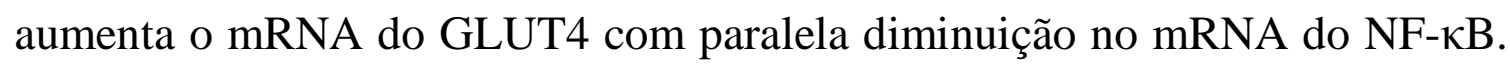
Entretanto, esse resultado não é suficiente para confirmar uma relação causa-

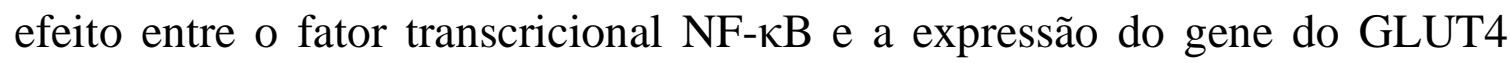
nessas condições. Para isso, é necessária a comprovação de que o NF-kB está ligado à elementos responsivos na região promotora do GLUT4 e assim inibindo a transcrição do gene com conseqüente diminuição do seu mRNA e proteína. 
Ampliando o conhecimento sobre os mecanismos envolvidos na expressão do gene do GLUT4 vislumbra-se a possibilidade de controlá-lo, contribuindo assim para corrigir alterações de sensibilidade à insulina que ocorrem na obesidade e / ou diabetes mellitus. 


\section{OBJETIVOS}

\subsection{Objetivo Geral}

- Investigar o efeito do jejum e da insulina sobre a expressão gênica do GLUT4, e a provável participação do fator

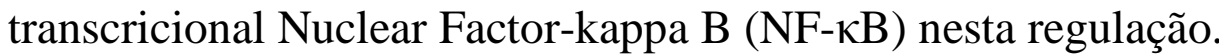

\subsection{Objetivos específicos}

- Investigar o efeito do jejum por 48 horas na expressão do mRNA

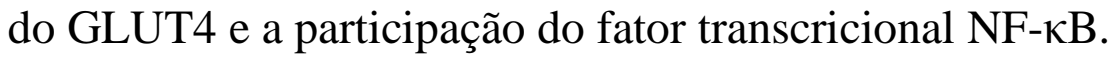

- Investigar, in vitro, o efeito da insulina na expressão do mRNA do GLUT4 e a participação do fator transcricional NF-אB.

- Investigar se essas regulações se refletem em alterações no conteúdo de proteína total de GLUT4. 


\section{MATERIAIS E MÉTODOS}

\section{$\underline{\text { 3.1. Animais }}$}

Utilizou-se para esta pesquisa ratos Wistar com dois meses de idade (180-200 g) provenientes do biotério do Instituto de Ciências Biomédicas da USP. Os animais foram mantidos no biotério de experimentação do Departamento de Fisiologia e Biofísica sob condições padronizadas de temperatura $\left(23 \pm 2{ }^{\circ} \mathrm{C}\right)$ e ciclo claro/escuro (12/12 horas diárias). Destes, retirou-se o músculo sóleo sob duas condições: alimentados ad libitum ou jejuados por 48 horas. Os procedimentos experimentais utilizados no presente estudo foram aprovados pela Comissão de Ética em Experimentação Animal (CEEA) do ICB da USP, protocolo $\mathrm{n}^{\circ} 031$.

\subsection{Incubação dos tecidos}

A incubação foi realizada após extração do músculo sóleo dos ratos jejuados por 48 horas. Seus tendões foram fixados em suporte inoxidável e em seguida incubado em 25 mL de solução Krebs-Henseleit Buffer (KHB), pH de 7,4 , acrescida de $1 \%$ de albumina sérica bovina, suplementada ou não com 
insulina regular $(16,7 \mathrm{nM})$, mantida em banho-maria a $37^{\circ} \mathrm{C}$ e oxigenada com $95 \%$ de $\mathrm{O}_{2}$ e $5 \%$ de $\mathrm{CO}_{2}$.

Os tecidos foram incubados por tempos distintos, renovando-se a solução a cada 40 minutos:

- 70 minutos $\left(40^{\prime}+30^{\prime}\right)$;

- 120 minutos $\left(40^{\prime}+40^{\prime}+40^{\prime}\right)$;

- 180 minutos $\left(40^{\prime}+40^{\prime}+40^{\prime}+40^{\prime}+20^{\prime}\right)$.

Após o período de incubação, os tecidos foram congelados em nitrogênio líquido para análise posterior.

\subsection{Quantificação do mRNA do GLUT4}

\subsubsection{Preparação dos tecidos}

O tecido foi homogeneizado em Polytron PT 3000 KINEMATICA $^{\circledR}$ (BRINKMAN) a $25.000 \mathrm{rpm}$ com Trizol $^{\circledR}$ Reagent (Invitrogen ${ }^{\mathrm{TM}}$ Life Technologies, Gaithersburg, USA) para isolamento do RNA total, obedecendo-se ao padrão de $0,1 \mathrm{~g}$ de tecido/ $1 \mathrm{~mL}$ de Trizol.

Seguiu-se uma centrifugação a $12000 \mathrm{rpm}$ por 10 minutos a $4{ }^{\circ} \mathrm{C}$, cujo sobrenadante foi separado e posteriormente acrescido com $0,2 \mathrm{~mL}$ de clorofórmio e $1 \mathrm{~mL}$ de Trizol para uma nova centrifugação a 12.000 rpm por 10 minutos a $4{ }^{\circ} \mathrm{C}$. A fase superior incolor foi retirada e acrescida com $0,5 \mathrm{~mL}$ 
de isopropanol. Após 10 minutos, seguiu-se uma nova centrifugação a 12.000 rpm por 10 minutos a $4{ }^{\circ} \mathrm{C}$ onde o sobrenadante foi descartado e o pellet foi lavado com etanol $70 \%$ e submetido a uma centrifugação a 10.000 rpm por 5 minutos a $4{ }^{\circ} \mathrm{C}$. Posteriormente, o sobrenadante foi removido e o precipitado seco em temperatura ambiente por 10 minutos. O pellet resultante foi ressuspenso em $50 \mu \mathrm{L}$ de água DEPC (Dietil Pirocarbonato) para solubilização em banho-maria a $65^{\circ} \mathrm{C}$ por 10 minutos.

\subsubsection{Avaliação da concentração de RNA total}

Para essa avaliação utilizou-se $1 \mu \mathrm{L}$ da amostra solubilizada de RNA total e $79 \mu \mathrm{L}$ de água DEPC para leitura em espectrofotômetro (Gene Quant, Amershan Pharmacia Biotech, Buckinghamshire, UK) em 260 nm. Essa leitura permite o cálculo da concentração de ácido nucléico da amostra. Uma unidade de densidade óptica (DO) corresponde a aproximadamente $40 \mu \mathrm{g} / \mathrm{mL}$ de fita simples e a relação Densidade Óptica 260/280 nm, sempre > 1,65 permite estimar a pureza do ácido nucléico da amostra.

\subsubsection{Northern Blotting}

O método utilizado foi descrito em OKAMOTO et al. (2004) e está sumarizado a seguir: 


\subsubsection{Eletroforese}

Após a preparação do gel de agarose $1 \%$ e a transferência deste para o sistema de corrida, adicionou-se o tampão de corrida.

O volume de amostra correspondente a $20 \mu \mathrm{g}$ de RNA foi adicionado com água DEPC (quando menor que $6 \mu \mathrm{L}$ ) e $19 \mu \mathrm{L}$ de mistura de reação (running buffer 10x, formaldeído e formamida) para incubação a $65^{\circ} \mathrm{C}$ por 10 minutos, seguido de uma incubação no gelo por 10 minutos. Adicionou-se então $2,5 \mu \mathrm{L}$ de tampão de aplicação (loading buffer) e $2 \mu \mathrm{L}$ de brometo de etídio para aplicação no gel.

A corrida eletroforética foi realizada sob corrente constante de $70 \mathrm{~mA}$ durante aproximadamente 2 horas num sistema de eletroforese horizontal submarina.

\subsubsection{Transferência}

Após a corrida eletroforética o gel foi lavado em água DEPC por 10 minutos e as amostras foram transferidas para uma membrana de nylon através do método de transferência por capilaridade.

Neste método, um sistema de ponte numa cuba de vidro contendo tampão 20x SSC foi montado com 3 folhas de papel filtro Whatman $3 \mathrm{MMChr}$ sobrepostas pelo gel. A membrana de nylon Hybond-N (Amershan Pharmacia 
Biotech, Buckinghamshire, UK) foi colocada sobre o gel e sobre esta mais 3 folhas de papel filtro. Sobre esse sistema adicionou-se uma camada de papel absorvente, uma placa de vidro e um peso. A transferência por capilaridade foi realizada durante 18 horas. Após este período a membrana lavada em tampão 2x SSC e então exposta a radiação ultravioleta $(254 \mathrm{~nm})$ por 3 minutos.

\subsubsection{Sondas}

Aproximadamente $25 \mathrm{ng}$ de cDNA de GLUT4 ou $\beta$-actina foram utilizados com $\left(\alpha-{ }^{32} \mathrm{P}\right)$ dCTP, utilizando-se "kit" Random Primers DNA Labeling System (Invitrogen ${ }^{\mathrm{TM}}$ Life Technologies, Gaithersburg, USA) para obtenção da sonda radioativa.

\subsubsection{Hibridação}

A membrana de nylon foi colocada em tubo de vidro com solução de pré-hibridação (6x SSC, 10x Denhardt's 1\% SDS, $100 \mu \mathrm{g} / \mathrm{mL}$ de DNA de esperma de salmão desnaturado e $\mathrm{H}_{2} \mathrm{O}$ MILI-Q) em um volume suficiente para mergulhar a membrana. Esta preparação permaneceu por 3 horas a $65{ }^{\circ} \mathrm{C}$. Posteriormente a sonda radioativa foi adicionada à solução de pré-hibridação e incubada a $65{ }^{\circ} \mathrm{C}$ por 18 horas. Após a hibridação a membrana foi lavada duas 
vezes em tampão de baixa estringência ( 2 x SSC com $0,1 \%$ SDS) e uma vez em tampão de alta estringência $(0,1 \mathrm{x}$ SSC com $0,1 \%$ SDS $)$ a $65^{\circ} \mathrm{C}$.

\subsubsection{Autorradiografia e densidade óptica}

As membranas foram colocadas em cassete RK e expostas a um filme Hyperfilm ${ }^{\circledR}$ (High Performance Radiografphy - Amersham Pharmacia Biotech, Buckimghamshire, UK) durante 4 dias. O filme foi revelado em solução reveladora GBX (Kodak Brasileira, São Paulo, Br) e fixado em solução fixadora GBX (Kodak Brasileira, São Paulo, Br) para análise posterior através de densitometria óptica em um analisador de imagens (SHARP J x 330) e utilizando-se o programa "Image Master 1D" (Pharmacia Biotech, Uppsala,SW).

\subsubsection{Normalização dos valores}

Para a correção da quantidade de RNA total das amostras aplicadas nos géis de agarose, utilizou-se uma sonda de cDNA de $\beta$-actina, cuja hibridação foi feita nas mesmas membranas, subseqüentemente à hibridação com a sonda de GLUT4. Os procedimentos para hibridação com essa sonda foram semelhantes ao descrito para a hibridação com o cDNA de GLUT4. 
Os resultados foram expressos em unidades arbitrárias (UA) a partir dos valores de GLUT4 normalizados pelos respectivos valores de $\beta$-actina e considerando 100 o valor obtido em cada experimento para os controles.

\subsection{Quantificação da atividade de ligação do fator transcricional NF-}

$\underline{\kappa B}$

\subsubsection{Extração de proteínas nucleares}

O método utilizado para a extração de proteínas nucleares descrito em ANDREWS \& FALLER (1991) está sumarizado a seguir.

O músculo sóleo foi triturado em suporte de cerâmica com nitrogênio líquido e colocado em tubo eppendorf com $1 \mathrm{~mL}$ de PBS 1x gelado para centrifugação a 1000 g por 10 minutos a $4{ }^{\circ} \mathrm{C}$. O sobrenadante foi descartado e o pellet ressuspenso em $500 \mu \mathrm{L}$ de tampão de lise gelado. Em seguida as amostras ficaram em repouso por 10 minutos no gelo para então adicionar 10 $\mu \mathrm{L}$ de NP-40 10\%. Após nova centrifugação a 12000 g por 30 segundos a $4{ }^{\circ} \mathrm{C}$ o sobrenadante foi descartado e o pellet ressuspenso em $100 \mu \mathrm{L}$ de tampão de extração gelado. Posteriormente as amostras ficaram em repouso por 20 minutos no gelo e então submetidas a uma centrifugação a 12000 g, por 2 minutos a $4{ }^{\circ} \mathrm{C}$. $\mathrm{O}$ sobrenadante contendo as proteínas nucleares foi aliquotado 
em eppendorf e estocado a $-70{ }^{\circ} \mathrm{C}$. A quantificação de proteínas nucleares foi realizada pelo método de Lowry (LOWRY et al., 1951).

\subsubsection{Preparação e marcação da sonda}

Para esta pesquisa utilizou-se como sonda o oligonucleotídeo consenso para NF-кB (5' - AGT TGA GGG GAC TTT CCC AGG C-3' - dupla fita). Para a reação utilizou-se $250 \mathrm{ng}$ do oligonucleotídeo de dupla fita, $2 \mu \mathrm{L}$ do tampão de enzima, $2 \mu \mathrm{L}$ da enzima fosfatase de camarão (Boehringer Mannhein) e água destilada autoclavada até completar o volume de $20 \mu \mathrm{L}$. Após incubação por 30 minutos a $37{ }^{\circ} \mathrm{C}$ e inativação da reação a $65^{\circ} \mathrm{C}$ por 15 minutos. O produto então foi purificado por meio do Kit QIAquick Nucleotide Removal (Quiagen) para posterior marcação radioativa.

A sonda foi marcada com $\gamma-{ }^{32} \mathrm{P}$ ATP numa solução contendo $1 \mu \mathrm{L}$ da enzima $\mathrm{T}_{4}$ PNK (Promega), $4 \mu \mathrm{L}$ de Exchange reaction buffer, $4 \mu \mathrm{L}$ de radioativo e $3 \mu \mathrm{L}$ de água bidestilada autoclavada. Após incubação por 90 minutos a $37{ }^{\circ} \mathrm{C}$, adicionou-se $80 \mu \mathrm{L}$ de água Milli-Q e o produto foi purificado em coluna de Sephadex por centrifugação a 14000 g por 20 minutos a $25^{\circ} \mathrm{C}$. Uma alíquota do produto $(1 \mu \mathrm{L})$ foi utilizada para contagem em contador $\beta$. 
3.4.3. Ensaio de mobilidade eletroforética (Eletrophoretic mobility shift assay-EMSA)

Em alíquotas contendo $20 \mu \mathrm{g}$ de proteínas nucleares adicionou-se $6 \mu \mathrm{L}$ de tampão de ligação, $1,5 \mu \mathrm{g}$ de Poli dI-dC, $1 \mu \mathrm{L}$ de sonda marcada radioativamente $(100.000 \mathrm{cpm})$ e água bidestilada para completar o volume em $15 \mu \mathrm{L}$.

Para eletroforese utilizou-se um gel de poliacrilamida $4 \%$ que foi submetido a uma pré-corrida a $90 \mathrm{~V}$ por 60 minutos a $4{ }^{\circ} \mathrm{C}$ em tampão TBE 0,5x. Após esse período o tampão foi trocado por um novo e as amostras aplicadas no gel. A eletroforese ocorre numa voltagem inicial de $90 \mathrm{~V}$ durante 30 minutos seguida por $150 \mathrm{~V}$ durante 2 horas.

Após a eletroforese o gel foi transferido para uma folha de papel filtro Whatman $3 \mathrm{MM}$ e secado a vácuo por 75 minutos a $80^{\circ} \mathrm{C}$ para em seguida ser exposto a um filme de RX (Hyperfilm ${ }^{\circledR}$-Amersham Pharmacia Biotech, Buckinghamshire, UK) em cassete a $-70^{\circ} \mathrm{C}$ por 4 dias.

A intensidade dos "blots" foi avaliada por densitometria óptica, utilizando-se o programa imlD - Pharmacia Biotech, Uppsala, SW e o resultado numérico foi expresso em unidades arbitrárias (UA), considerandose o controle de cada experimento como 100. 


\subsection{Quantificação da proteína GLUT4}

\subsubsection{Preparação dos tecidos}

As amostras foram homogeneizadas em Polytron PT 3000 KINEMATICA ${ }^{\circledR}($ BRINKMAN) a $24.000 \mathrm{rpm}$ durante $30 \mathrm{~s}$ em tampão de homogeneização (Tris $\mathrm{HCl}$ 10mM; EDTA 1,0mM; sacarose $250 \mathrm{mM}$ ) numa proporção de 1:6 (peso:volume). Posteriormente, foram centrifugadas a 1000 g por 10 minutos a $4{ }^{\circ} \mathrm{C}$ e o precipitado foi ressuspenso e novamente centrifugado a $1000 \mathrm{~g}$ por 10 minutos a $4{ }^{\circ} \mathrm{C}$. Os dois sobrenadantes foram somados e submetidos a uma centrifugação a 41.000 g por 75 minutos a $4{ }^{\circ} \mathrm{C}$. O pellet resultante foi ressuspenso em tampão de homogeneização, sonicado até sua dissolução e estocado a uma temperatura de $-70{ }^{\circ} \mathrm{C}$.

\subsubsection{Determinação da concentração de proteínas:}

A concentração de proteínas totais nas amostras foi determinada pelo método de Lowry (LOWRY et al., 1951).

Conhecidas as concentrações de proteínas totais das amostras, as mesmas foram submetidas ao método de Western Blotting para a quantificação da proteína transportadora de glicose GLUT4, o que envolveu as seguintes etapas: 


\subsubsection{Western Blotting}

Utilizou-se o método desenvolvido por Laemmli e modificado por Garfin (GARFIN, 1990) que envolve um sistema descontínuo de dois géis contíguos, o gel de empacotamento (stacking gel) e o gel de separação (resolving gel).

Aplicou-se no gel $30 \mu \mathrm{g}$ de proteínas totais de cada amostra acrescidas de Laemmli com $6 \%$ de 2-mercaptoetanol. A eletroforese se inicia com a corrida no gel de empacotamento sob voltagem constante em $70 \mathrm{mV}$ até que ocorra a transição dos géis, para então aplicar uma corrente constante de 65 mA para a corrida no gel de separação por 5 horas. Durante esse processo utilizou-se um padrão de proteínas de pesos moleculares conhecidos para possibilitar a localização da proteína em estudo.

\subsubsection{Transferência Eletroforética}

Após a separação das frações protéicas no gel de poliacrilamida realizou-se sua transferência eletroforética para uma membrana de nitrocelulose Hybond ${ }^{\mathrm{TM}}-\mathrm{ECL}^{\mathrm{TM}}$ (Amersham, Buckinghahmshire, UK) sob corrente constante de $42 \mathrm{~mA}$ durante $16 \mathrm{~h}$ a $4{ }^{\circ} \mathrm{C}$.

A qualidade da transferência foi verificada corando-se o gel com azul brilhante de coomasie (TOWBIN et al., 1979). 


\subsubsection{Imunodetecção por Enhanced Chemiluminescence (ECL)}

Após a transferência eletroforética a membrana de nitrocelulose foi submetida ao procedimento de imunodetecção de proteínas específicas, seguido de quantificação por quimioluminescência.

Para isso iniciou-se um bloqueio inespecífico da membrana com leite em pó desnatado 8\% diluído em PBS 1X, pH 7,2 [NaCl 0,8\%; $\mathrm{Na}_{2} \mathrm{HPO}_{4} \cdot\left(12 \mathrm{H}_{2} \mathrm{O}\right) 0,115 \%$; $\left.\mathrm{Kcl} 0,02 \% ; \mathrm{KH}_{2} \mathrm{PO}_{4} 0,02 \%\right]$ por 1 hora sob agitação constante.

Seguiu-se uma incubação com anticorpo primário anti-GLUT4 diluído (Polyclonal Rabbit Raised Anti-GLUT4, Chemicon International Inc, Temecula, CA, USA) em PBS 1X (BSA 8\%) 1:3000 por 3 horas a $37{ }^{\circ} \mathrm{C}$, sob agitação constante, seguida de lavagens em solução PBS-T (PBS 1X - Tween $20-0,1 \%$ ) para retirada do excesso de anticorpo primário.

Incubou-se então com anticorpo secundário com HRP (Horse Radish Peroxidase) (1:10.000) em PBS 1X (BSA 1\%) por 1 hora, sob agitação e temperatura ambiente, seguido de novas lavagens com PBS-T\%) para retirada do excesso de anticorpo secundário.

Para detecção, incubou-se a membrana numa solução detecção contendo as soluções 1 (luminol $2.5 \mathrm{mM}$, ácido p-cumárico 400 mM e Tris pH $8.51 \mathrm{M}$ ) e $2(\mathrm{H} 2 \mathrm{O} 25.4 \mathrm{mM}$ e Tris $\mathrm{pH} 8.51 \mathrm{M})$ por 1 minuto. 


\subsubsection{Densitometria Óptica}

A membrana foi exposta ao filme de RX (Hyperfilm - Amersham, Buckinghamshire, UK) por aproximadamente 5 minutos. O filme foi revelado com solução reveladora e reforçadora GBX e solução fixadora e reforçadora GBX (Kodak Brasileira, São Paulo, BR).

A intensidade dos "blots" foi avaliada por densitometria óptica, utilizando-se o programa imlD - Pharmacia Biotech, Uppsala, SW e o resultado numérico foi expresso em unidades arbitrárias (UA) em relação à quantidade de proteína aplicada para a eletroforese e considerando-se o controle de cada experimento como 100.

\subsection{Análise estatística dos resultados}

Os resultados foram expressos como média \pm EPM. A avaliação dos resultados foi realizada através da comparação das médias, utilizando o teste ANOVA, paramétrico, com pós-teste quando necessário (Student-NewmanKeuls ou Bonferroni). As diferenças entre os grupos foram consideradas significantes quando $P<0,05$. 


\section{RESULTADOS}

\subsection{Efeito do jejum na expressão do mRNA do GLUT4}

Não houve diferença significativa entre o peso dos ratos $(p>0,05)$ e o peso do músculo dos ratos ( $p>0,05)$. Valores obtidos da média \pm E.P.M. de 6 animais, One-Way ANOVA.

O jejum por 48 horas propiciou uma redução de aproximadamente $24 \%$ ( $\mathrm{p}<0,05)$ na expressão do mRNA do GLUT4 no músculo sóleo ao compará-lo com os animais alimentados ad libitum. A incubação por 70 minutos do músculo sóleo em solução sem glicose e insulina reverteu essa mudança aumentando a expressão do mRNA do GLUT4 em 38\% (p<0,05), superando inclusive o grupo alimentado.

Tabela 1: Peso (g) dos ratos alimentados, jejuados e jejuados com músculo submetido à incubação.

\begin{tabular}{|c|c|c|}
\hline Alimentado & Jejuado & Incubado \\
\hline 198 & 184 & 190 \\
\hline 198 & 197 & 186 \\
\hline 200 & 197 & 191 \\
\hline 200 & 180 & 193 \\
\hline 190 & 180 & 197 \\
\hline 195 & 195 & 180 \\
\hline
\end{tabular}

Tabela 2: Peso (g) do músculo dos ratos alimentados, jejuados e jejuados com músculo submetido à incubação

\begin{tabular}{|c|c|c|}
\hline Alimentado & Jejuado & Incubado \\
\hline 0,08 & 0,09 & 0,09 \\
\hline 0,08 & 0,09 & 0,10 \\
\hline 0,08 & 0,10 & 0,09 \\
\hline 0,08 & 0,09 & 0,09 \\
\hline 0,08 & 0,10 & 0,08 \\
\hline 0,09 & 0,07 & 0,08 \\
\hline
\end{tabular}


A $\quad$ J $\quad$ I

GLUT4

$\beta$-actina

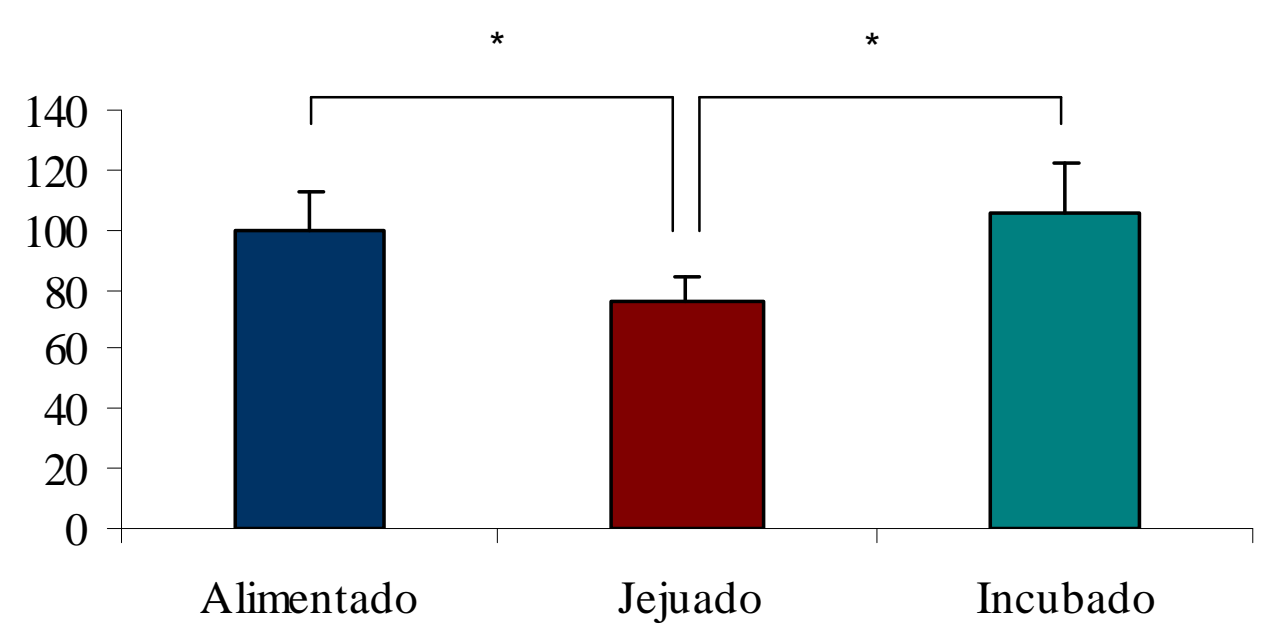

Figura 1: Efeito do jejum e da incubação na expressão do mRNA do GLUT4. Análise da expressão do mRNA do GLUT4 no músculo sóleo de ratos alimentados ad libitum (A), jejuados por 48 horas (J) e músculo submetido à incubação por 70 minutos em solução KHB pura (I). No alto, imagem típica do mRNA de GLUT4 e $\beta$-actina. Os valores são média \pm E.P.M. de 6 animais. ${ }^{*} \mathrm{p}<0,05$, One-Way ANOVA com Student-Newman-Keuls. 
4.2.Efeito do jejum na atividade de ligação do fator transcricional NF-

$\underline{\kappa \mathrm{B}}$

Não houve diferença significativa entre o peso dos ratos $(p>0,05)$ e o peso do músculo dos ratos $(\mathrm{p}>0,05)$ conforme tabelas abaixo. Valores obtidos da média \pm E.P.M. de 8 animais, One-Way ANOVA.

Ratos jejuados por 48 horas apresentaram aumento da atividade de ligação do fator transcricional NF- $\mathrm{BB}$ ao DNA em $51 \%(\mathrm{p}<0,01)$ no músculo sóleo em relação aos ratos alimentados e a incubação em tampão KHB do músculo dos ratos jejuados reverteu o efeito do jejum $(\mathrm{p}<0,01)$.

Tabela 3: Peso (g) dos ratos alimentados, jejuados e jejuados com músculo submetido à incubação.

\begin{tabular}{|c|c|c|}
\hline Alimentado & Jejuado & Incubado \\
\hline 190 & 190 & 186 \\
\hline 200 & 187 & 187 \\
\hline 190 & 187 & 190 \\
\hline 198 & 185 & 180 \\
\hline 198 & 185 & 180 \\
\hline 200 & 195 & 185 \\
\hline 190 & 180 & 197 \\
\hline 180 & 195 & 187 \\
\hline
\end{tabular}

Tabela 4: Peso (g) do músculo dos ratos alimentados, jejuados e jejuados com músculo submetido à incubação

\begin{tabular}{|c|c|c|}
\hline Alimentado & Jejuado & Incubado \\
\hline 0,07 & 0,08 & 0,08 \\
\hline 0,09 & 0,09 & 0,08 \\
\hline 0,07 & 0,09 & 0,09 \\
\hline 0,11 & 0,08 & 0,08 \\
\hline 0,09 & 0,07 & 0,08 \\
\hline 0,10 & 0,09 & 0,09 \\
\hline 0,10 & 0,10 & 0,09 \\
\hline 0,08 & 0,07 & 0,08 \\
\hline
\end{tabular}


A $\quad$ J I
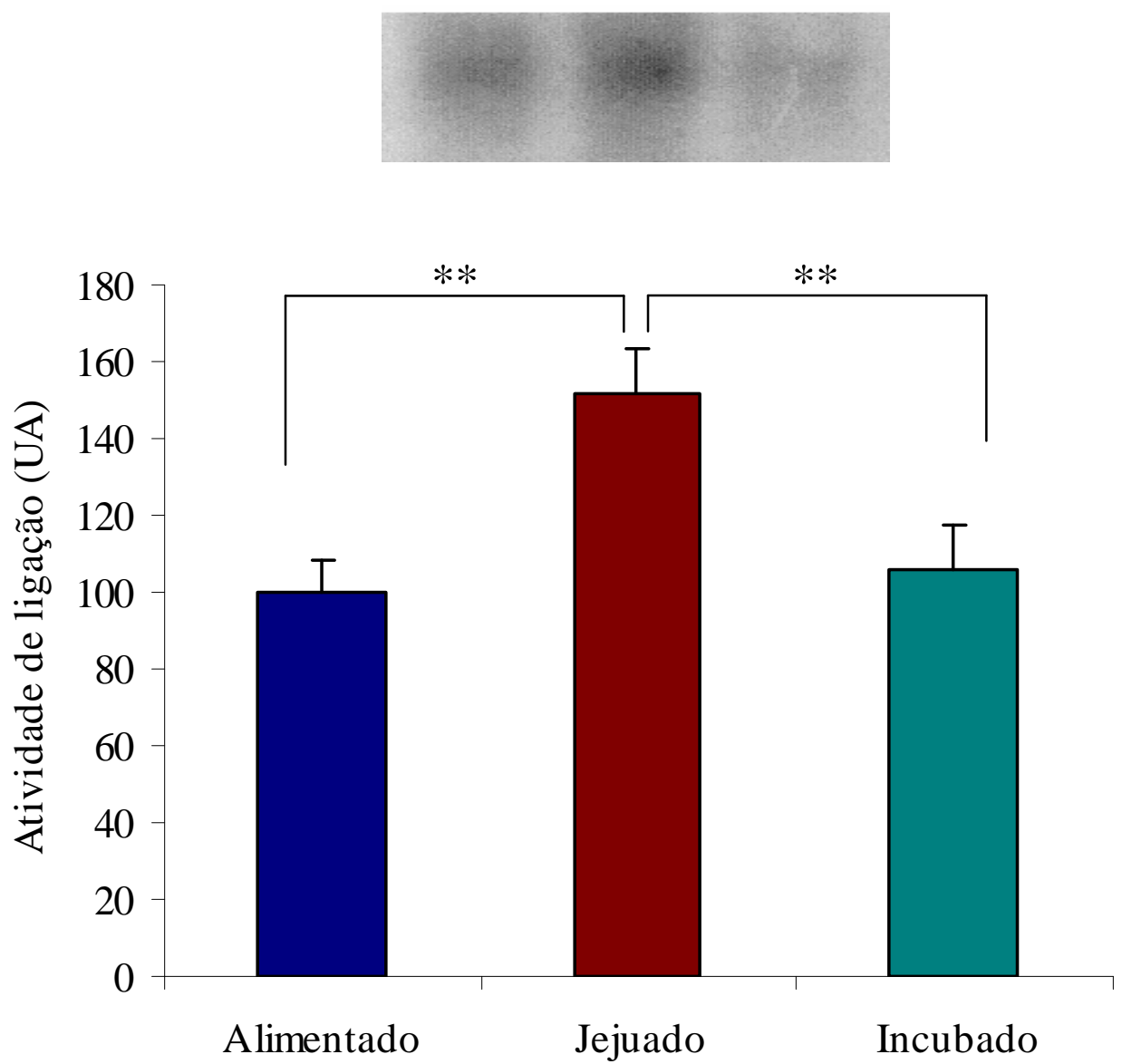

Figura 2: Efeito do jejum e da incubação na atividade de ligação do fator

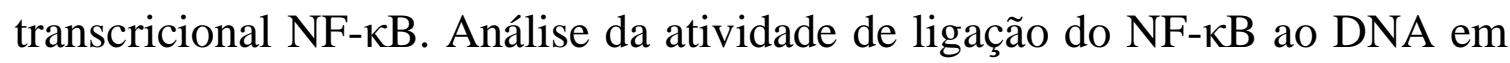
extrato nuclear do músculo sóleo de ratos alimentados (A), jejuados por 48 horas $(\mathrm{J})$ e músculo submetido a incubação por 70 minutos em solução KHB pura (I). No alto, blots referente à atividade de ligação. Os resultados são expressos em unidades arbitrárias (UA). Os valores são média \pm E.P.M. de 8 animais. ${ }^{*} \mathrm{p}<0,01$, One-Way ANOVA com Studant-Newman-Keuls. 


\subsection{Efeito do jejum no conteúdo protéico de GLUT4}

Não houve diferença significativa entre o peso dos ratos $(p>0,05)$ e o peso do músculo dos ratos $(\mathrm{p}>0,05)$ conforme tabelas abaixo. Valores obtidos da média \pm E.P.M. de 6 animais, One-Way ANOVA.

Ratos jejuados por 48 horas apresentaram diminuição do conteúdo protéico total de GLUT4 em 30\% ( $\mathrm{p}<0,01)$ no músculo sóleo em relação aos ratos alimentados. Não houve diferença significativa entre o conteúdo protéico total do músculo sóleo dos ratos jejuados em relação ao conteúdo de músculo submetido à incubação.

Tabela 5: Peso (g) dos ratos alimentados, jejuados e jejuados com músculo submetido à incubação.

\begin{tabular}{|c|c|c|}
\hline Alimentado & Jejuado & Incubado \\
\hline 200 & 184 & 200 \\
\hline 200 & 189 & 177 \\
\hline 190 & 189 & 183 \\
\hline 190 & 171 & 193 \\
\hline 194 & 171 & 196 \\
\hline 187 & 184 & 177 \\
\hline
\end{tabular}

Tabela 6: Peso (g) do músculo dos ratos alimentados, jejuados e jejuados com músculo submetido à incubação

\begin{tabular}{|c|c|c|}
\hline Alimentado & Jejuado & Incubado \\
\hline 0,09 & 0,10 & 0,09 \\
\hline 0,08 & 0,09 & 0,09 \\
\hline 0,09 & 0,08 & 0,10 \\
\hline 0,06 & 0,07 & 0,08 \\
\hline 0,08 & 0,07 & 0,08 \\
\hline 0,07 & 0,09 & 0,10 \\
\hline
\end{tabular}


A $\quad$ J $\quad$ I
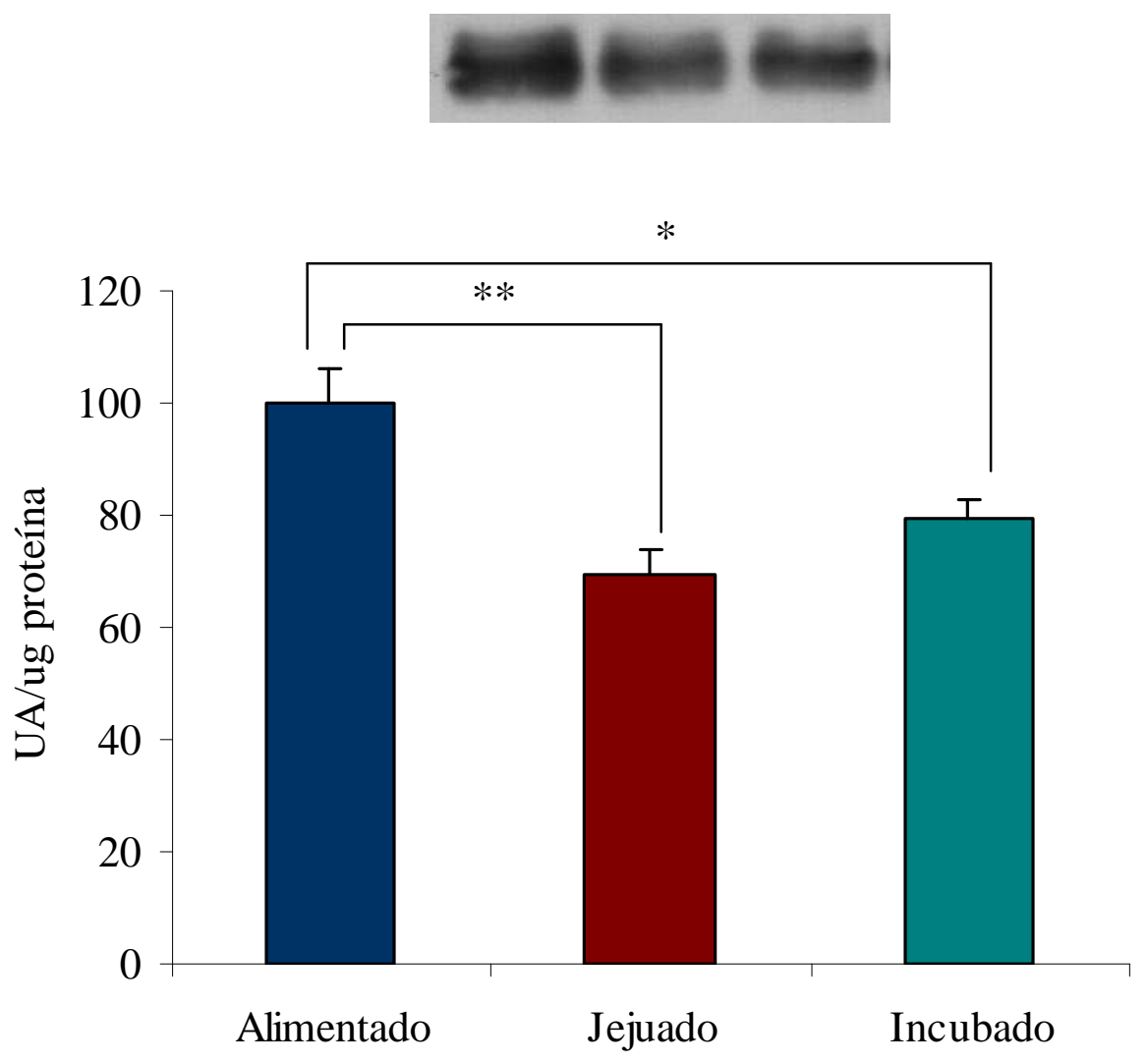

Figura 3: Efeito do jejum e da incubação no conteúdo protéico total de GLUT4. Análise do conteúdo protéico total de GLUT4 no músculo sóleo de ratos alimentados (A), jejuados (J) e jejuados com músculo submetido à incubação por 70 minutos em solução KHB pura (I). No alto, imagem típica dos blots referentes à proteína GLUT4. Os resultados são expressos em UA/ $\mu \mathrm{g}$ de proteína considerando-se o controle do experimento como 100. Os valores são média \pm E.P.M. de 6 animais. ${ }^{*} p<0,05, * * p<0,01$, One-Way ANOVA com Studant-Newman-Keuls. 


\subsection{Efeito da insulina na expressão do mRNA do GLUT4}

Não houve diferença significativa entre o peso dos ratos $(p>0,05)$ e o peso do músculo dos ratos (p>0,05). Valores obtidos da média \pm E.P.M. de 6 animais, One-Way ANOVA.

Tabela 7:Peso (g) dos ratos com músculo submetido à incubação.

\begin{tabular}{|c|c|c|c|c|c|}
\hline P7 & I7 & P12 & I12 & P18 & I18 \\
\hline 190 & 187 & 181 & 185 & 181 & 181 \\
\hline 186 & 193 & 185 & 200 & 200 & 200 \\
\hline 191 & 187 & 200 & 182 & 200 & 200 \\
\hline 193 & 191 & 200 & 200 & 196 & 196 \\
\hline 197 & 190 & 190 & 190 & 180 & 180 \\
\hline 180 & 183 & 183 & 182 & 181 & 181 \\
\hline
\end{tabular}

Tabela 8: Peso (g) do músculo submetido à incubação.

\begin{tabular}{|c|c|c|c|c|c|}
\hline P7 & I7 & P12 & I12 & P18 & I18 \\
\hline 0,09 & 0,09 & 0,09 & 0,10 & 0,1 & 0,09 \\
\hline 0,10 & 0,09 & 0,11 & 0,10 & 0,09 & 0,09 \\
\hline 0,09 & 0,09 & 0,09 & 0,08 & 0,09 & 0,10 \\
\hline 0,09 & 0,08 & 0,09 & 0,10 & 0,10 & 0,09 \\
\hline 0,08 & 0,09 & 0,09 & 0,09 & 0,09 & 0,09 \\
\hline 0,08 & 0,08 & 0,09 & 0,08 & 0,09 & 0,09 \\
\hline
\end{tabular}

Músculos sóleos de ratos jejuados, quando incubados por 70 minutos em solução KHB com insulina $(16,7 \mathrm{nM})$, apresentaram um aumento na expressão do mRNA do GLUT4 de 37\% (p<0,05) em relação à incubação pelo mesmo período com solução KHB pura.

O prolongamento do período de incubação para 120 e 180 minutos proporcionou um aumento da expressão do mRNA do GLUT4 tanto na 
incubação com solução KHB pura como na incubação com insulina (16.7 nM). No entanto, a incubação com insulina sempre apresentou valores maiores que a incubação com tampão puro, sendo aproximadamente $30 \%$ maior na em 120 minutos $(\mathrm{p}<0,05)$ e $25 \%$ maior em 180 minutos $(\mathrm{p}<0,05)$. 
$\begin{array}{llllll}\text { P7 } & \text { I7 } & \text { P12 } & \text { I12 } & \text { P18 } & \text { I18 }\end{array}$

GLUT4

B-actina

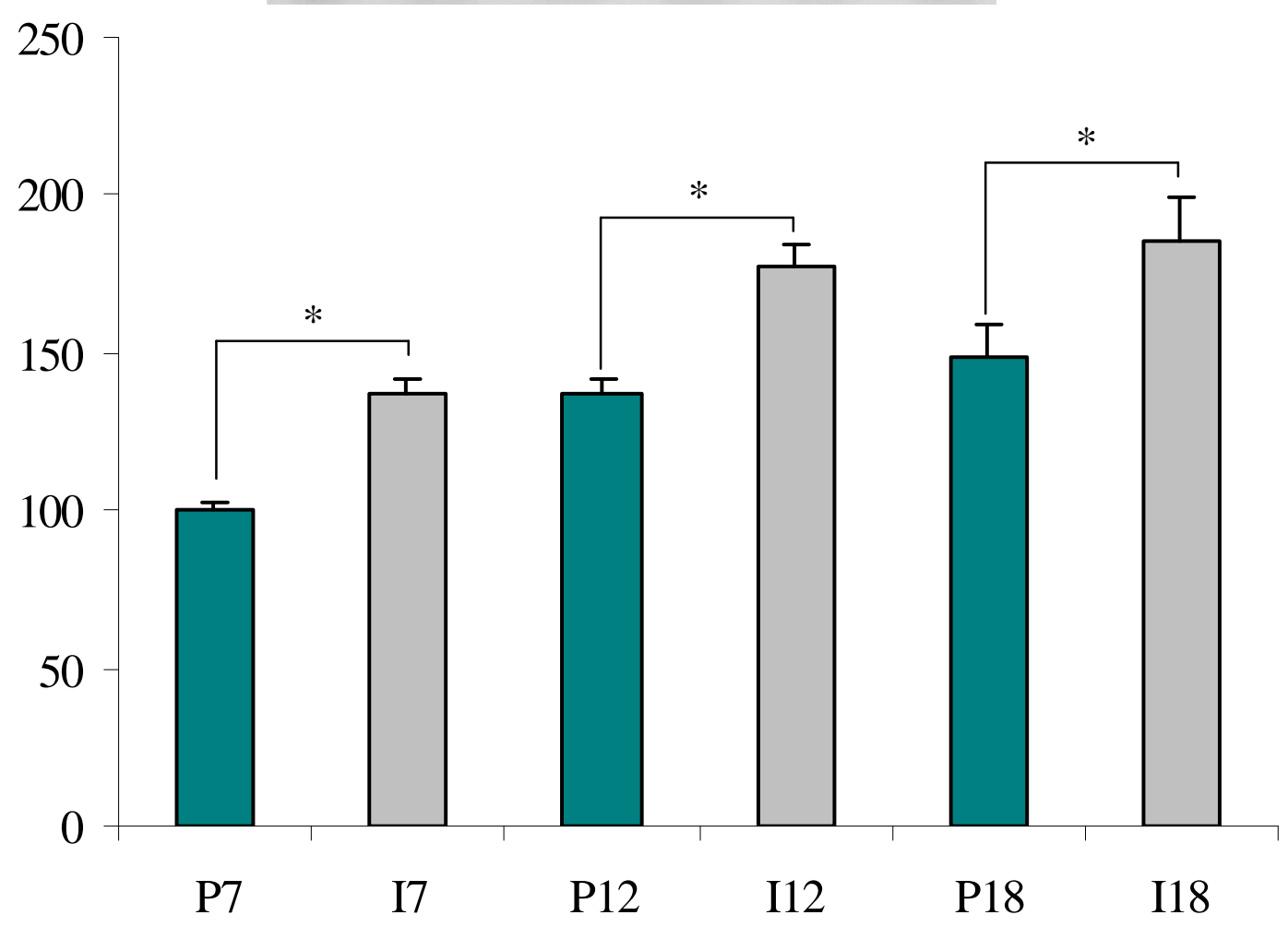

Figura 4: Efeito da insulina na expressão do mRNA do GLUT4. Análise da expressão do mRNA do GLUT4 foi verificada no músculo sóleo de ratos jejuados por 48 horas. O músculo foi submetido à incubação por 70 (P7), 120 (P12) e 180 minutos (P18) em solução KHB pura ou acrescida de 16,7nM de insulina, (I7), (I12), (I18) respectivamente. No alto, imagem típica do mRNA de GLUT4 e $\beta$-actina. Os resultados são expressos em unidades arbitrárias (UA) a partir dos valores de GLUT4 normalizados pelos respectivos valores de $\beta$-actina e considerando o controle do experimento como 100. Os valores são média \pm E.P.M. de 6 animais. Análise da expressão do mRNA de GLUT4 utilizando-se Two-Way ANOVA e Bonferroni como pós-teste: tempo, $p<0,0001$; tratamento, $p<0,0001$; interação, $\mathrm{p}=0,97 ; * \mathrm{p}<0,05$ vs incubação com insulina. 
4.5.Efeito da insulina na atividade de ligação do fator transcricional $\underline{N F-\kappa \mathrm{B}}$

Não houve diferença significativa entre o peso dos ratos $(p>0,05)$ e o peso do músculo dos ratos ( $p>0,05)$. Valores obtidos da média \pm E.P.M. de 5 animais, One-Way ANOVA.

Tabela 9: Peso (g) dos ratos jejuados com músculo submetidos à incubação.

\begin{tabular}{|c|c|c|c|c|c|}
\hline P7 & I7 & P12 & I12 & P18 & I18 \\
\hline 190 & 186 & 182 & 198 & 190 & 186 \\
\hline 180 & 190 & 186 & 196 & 188 & 188 \\
\hline 180 & 185 & 198 & 186 & 187 & 190 \\
\hline 185 & 185 & 199 & 199 & 196 & 196 \\
\hline 197 & 197 & 193 & 190 & 197 & 197 \\
\hline
\end{tabular}

Tabela 10: Peso (g) do músculo submetido à incubação.

\begin{tabular}{|c|c|c|c|c|c|}
\hline P7 & I7 & P12 & I12 & P18 & I18 \\
\hline 0,09 & 0,07 & 0,08 & 0,07 & 0,08 & 0,08 \\
\hline 0,08 & 0,08 & 0,09 & 0,09 & 0,08 & 0,07 \\
\hline 0,08 & 0,06 & 0,09 & 0,09 & 0,09 & 0,08 \\
\hline 0,09 & 0,08 & 0,10 & 0,11 & 0,09 & 0,08 \\
\hline 0,09 & 0,09 & 0,09 & 0,08 & 0,10 & 0,09 \\
\hline
\end{tabular}

Músculos sóleos de ratos jejuados, quando incubados por 70 minutos em solução KHB acrescida de 16,7 nM de insulina apresentaram diminuição de $30 \%(\mathrm{p}<0,05)$ da atividade de ligação do fator transcricional NF- $\mathrm{KB}$ ao DNA em relação à incubação pelo mesmo período com solução KHB puro. 
A incubação em solução KHB acrescida de $16,7 \mathrm{nM}$ de insulina durante 120 e 180 minutos apresentou um diminuição ainda maior, $40 \%(\mathrm{p}<0,001)$ e $50 \%(\mathrm{p}<0,001)$ respectivamente, na atividade de ligação do fator transcricional NF- $\mathrm{B}$ ao DNA. A incubação por este mesmo período com solução KHB pura não apresentou mudança significativa na atividade de ligação. 


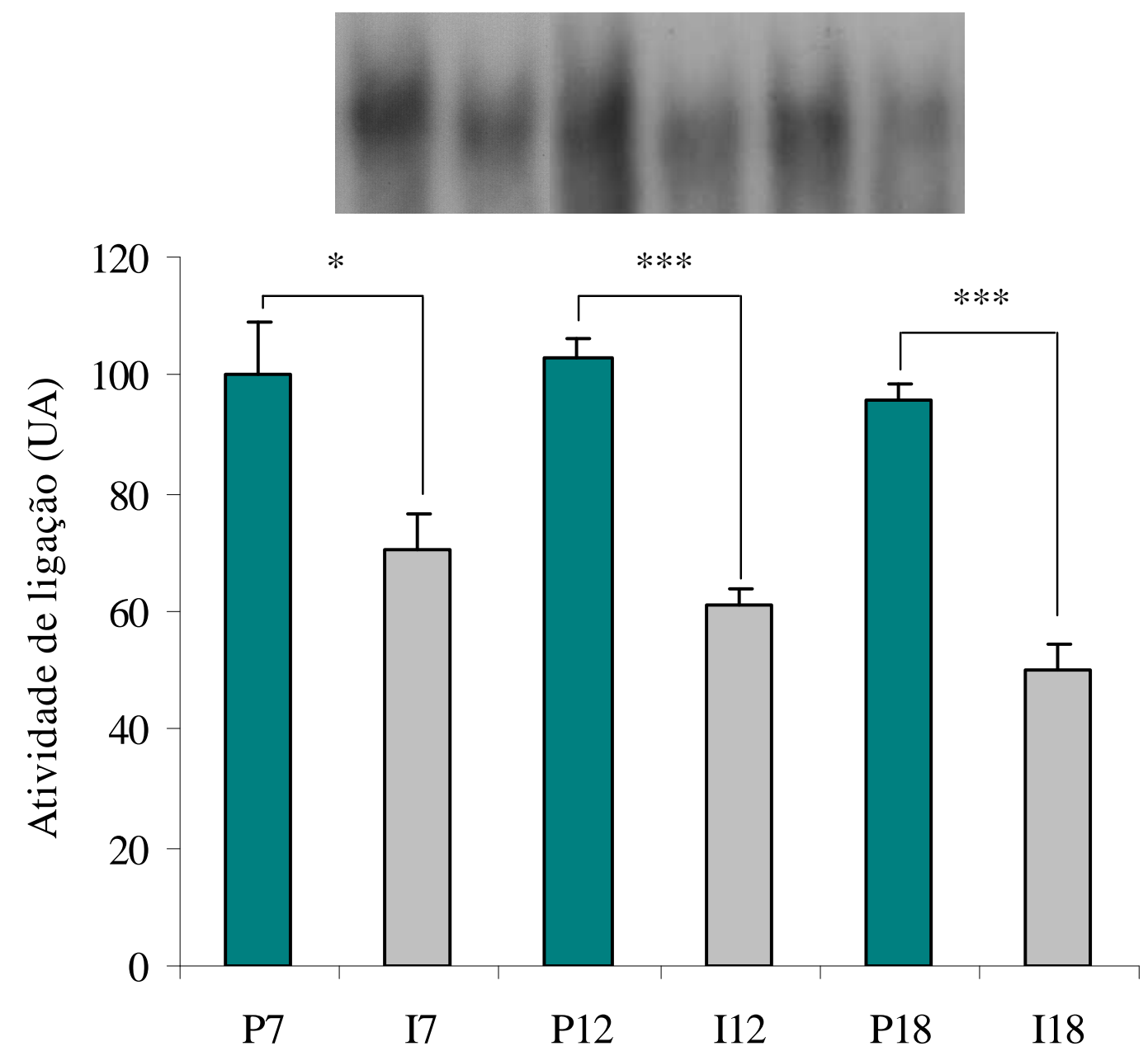

Figura 5: Efeito da insulina na atividade de ligação do fator transcricional NF- $k B$ ao DNA. Análise da atividade de ligação do NF-kB ao DNA em extrato nuclear foi verificada no músculo sóleo de ratos jejuados por 48 horas. $\mathrm{O}$ músculo foi submetido à incubação durante 70 (P7), 120 (P12) e 180 minutos (P18) em solução KHB pura ou acrescida de $16,7 \mathrm{nM}$ de insulina, (I7), (I12), (I18) respectivamente. No alto, blots referentes à atividade de ligação. Os resultados são expressos em unidades arbitrárias (UA) considerando-se o controle do experimento como 100. Os valores são média \pm E.P.M. de 6 animais. Análise da atividade de ligação utilizando-se Two-Way ANOVA e Bonferroni como pós-teste: tempo, $\mathrm{P}=0,17$; tratamento, $\mathrm{P}<0,0001$; interação, $\mathrm{P}=0,44 ; * \mathrm{P}<0,05, * * * \mathrm{P}<0,001$, vs incubação com insulina. 


\subsection{Efeito da insulina no conteúdo protéico de GLUT4}

Não houve diferença significativa entre o peso dos ratos $(p>0,05)$ e o peso do músculo dos ratos $(\mathrm{p}>0,05)$ conforme tabelas abaixo. Valores obtidos da média \pm E.P.M. de 6 animais, One-Way ANOVA.

Tabela 11: Peso (g) dos ratos jejuados com músculo submetido à incubação.

\begin{tabular}{|c|c|c|c|c|c|}
\hline P7 & I7 & P12 & I12 & P18 & I18 \\
\hline 200 & 200 & 177 & 177 & 200 & 200 \\
\hline 177 & 193 & 186 & 186 & 199 & 199 \\
\hline 183 & 194 & 196 & 178 & 177 & 197 \\
\hline 193 & 196 & 178 & 196 & 191 & 191 \\
\hline 196 & 199 & 188 & 180 & 191 & 191 \\
\hline 177 & 180 & 195 & 182 & 177 & 192 \\
\hline
\end{tabular}

Tabela 12: Peso (g) do músculo incubado dos ratos jejuados.

\begin{tabular}{|c|c|c|c|c|c|}
\hline P7 & I7 & P12 & I12 & P18 & I18 \\
\hline 0,09 & 0,08 & 0,09 & 0,08 & 0,09 & 0,08 \\
\hline 0,09 & 0,08 & 0,07 & 0,09 & 0,08 & 0,09 \\
\hline 0,10 & 0,08 & 0,08 & 0,09 & 0,09 & 0,09 \\
\hline 0,08 & 0,09 & 0,08 & 0,09 & 0,10 & 0,09 \\
\hline 0,08 & 0,09 & 0,09 & 0,09 & 0,10 & 0,09 \\
\hline 0,10 & 0,08 & 0,08 & 0,09 & 0,07 & 0,10 \\
\hline
\end{tabular}

Músculos sóleos de ratos jejuados submetidos à incubação com insulina $(16,7 \mathrm{nM})$ por 70 minutos apresentaram aumento do conteúdo protéico total de GLUT4 em 33\% (p<0,05) em relação à incubação com tampão KHB puro. O prolongamento para 120 e 180 minutos de incubação na presença de insulina (16,7 nM) do músculo sóleo de ratos jejuados por 48 horas representou um aumento ainda maior, $40 \%(\mathrm{p}<0,05)$ e $54 \%(\mathrm{p}<0,001)$ respectivamente, do conteúdo protéico total de GLUT4 em relação ao mesmo período com tampão KHB puro. 


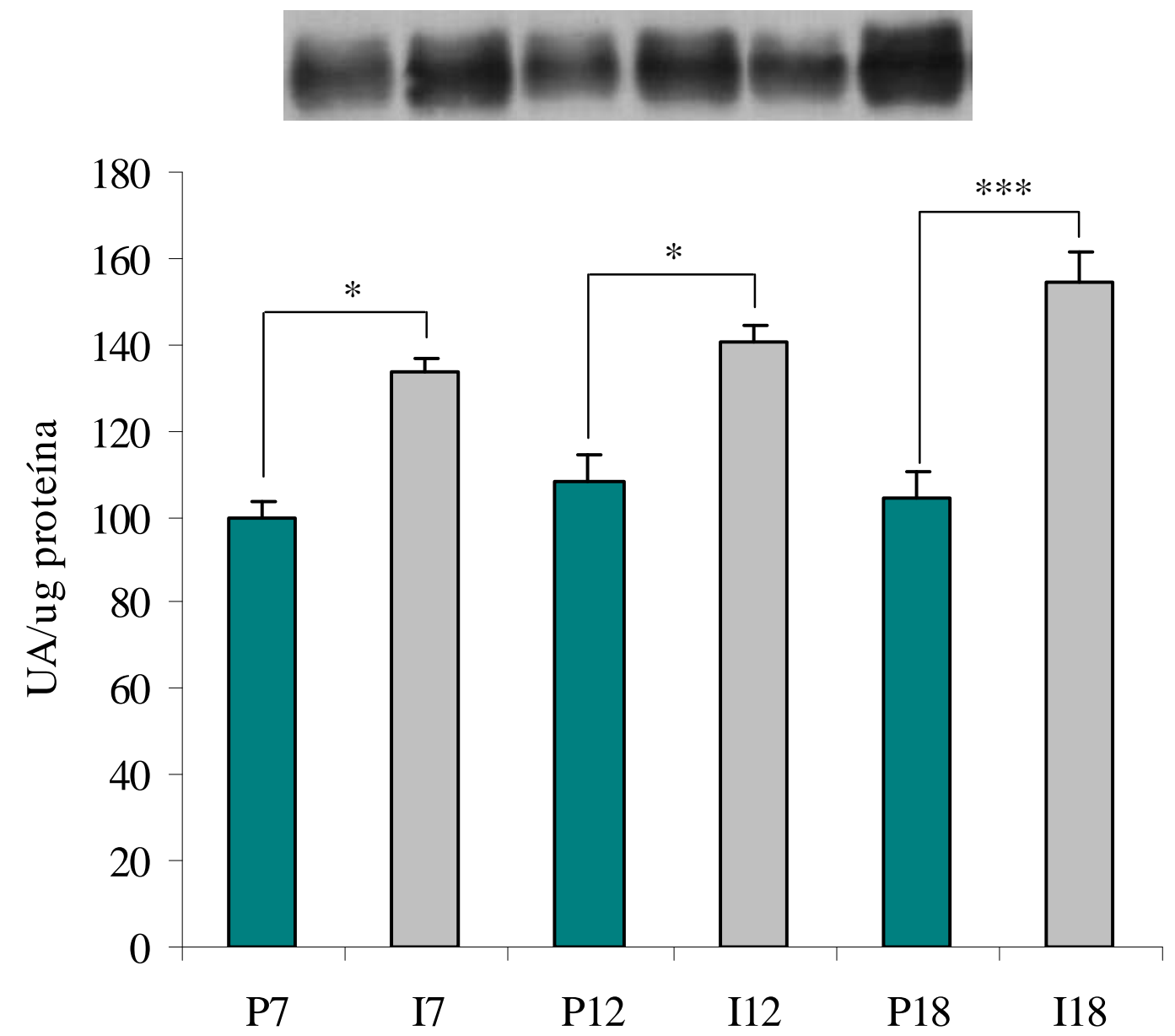

Figura 6: Efeito da insulina no conteúdo protéico total de GLUT4. Análise do conteúdo protéico total de GLUT4 no músculo sóleo de ratos jejuados por 48 horas. O músculo foi submetido à incubação por 70 (P7), 120 (P12) e 180 minutos (P18) em solução KHB pura ou acrescida de 16,7nM de insulina, (I7), (I12), (I18) respectivamente. No alto, imagem típica dos blots referentes à proteína GLUT4. Os resultados são expressos em UA/ $\mu$ g de proteína considerando-se o controle do experimento como 100. Os valores são média \pm E.P.M. de 6 animais. Análise do conteúdo protéico total de GLUT4 utilizando-se Two-Way ANOVA e Bonferroni como pós-teste: tempo, $\mathrm{p}=0,33$; tratamento, $\mathrm{p}<0,0001$; interação, $\mathrm{p}=0,51 ; * \mathrm{p}<0,05, * * * \mathrm{p}<0,001$, vs incubação com insulina. 


\section{DISCUSSÃO}

Embora o efeito da insulina na translocação do GLUT4 esteja bem definido, o conhecimento sobre sua transcrição ainda não está claro. Conhecer os mecanismos envolvidos na expressão do gene do GLUT4 gera a possibilidade de controlá-lo, contribuindo assim para prevenir ou sanar alterações de sensibilidade à insulina como as que ocorrem na obesidade e no diabetes mellitus.

Buscando esse conhecimento, esta pesquisa avaliou inicialmente a regulação induzida pelo jejum prolongado (48 horas) na expressão gênica do GLUT4. Essa condição proporcionou uma diminuição na expressão do mRNA do GLUT4. Pesquisas recentes (NORTON et al., 2007, ZANQUETTA et al., 2006 e SILVA et al., 2005) demonstraram resultados semelhantes.

É possível que essa mudança esteja relacionada com as alterações metabólicas, hormonais e neurais provocadas pelo jejum prolongado. Sabe-se que o jejum prolongado é associado com diminuição da glicemia e da concentração de insulina, além do aumento da concentração de aminoácidos, ácidos graxos livres ou de hormônios contra-reguladores na corrente sangüínea. Esses fatores poderiam alterar a expressão de determinado fator transcricional que atuaria na regulação da transcrição do gene do GLUT4. 
De fato, o fator transcricional NF- $\mathrm{KB}$ que atua como um inibidor do gene do GLUT4 (RUAN et al., 2002), foi utilizado em pesquisa anterior realizada pelo nosso laboratório onde o sóleo de ratos jejuados por 48 horas apresentou aumento no mRNA do fator transcricional NF- $\kappa B$ (SILVA et al, 2005).

Para confirmar a participação do fator NF-אB na regulação da expressão do GLUT4 nessas condições foi necessário avaliar sua atividade de ligação ao DNA. Através do ensaio de mobilidade eletroforética (EMSA) foi possível verificar que o jejum por 48 horas provocou um aumento na atividade de

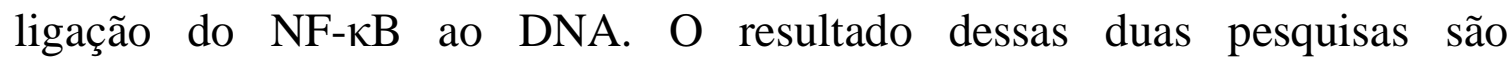
complementares e confirmam a participação do NF-אB nesta modulação.

Fatores distintos poderiam atuar no jejum prolongado para conduzir ao aumento da atividade de ligação do NF-אB. A elevação na secreção de hormônios contra-reguladores (glicocorticóides) (EVANS-STORMS \& CIDLOWSKI, 2000), o estresse oxidativo aumentando a produção de espécies reativas de oxigênio tais como o peróxido de hidrogênio (BOWIE \& O'NEILL, 2000) que propicia a degradação de IкB no decorrer do jejum prolongado (CUERVO et al., 1998).

Outro fator que deve ser considerado é o aumento da concentração plasmática de AGL. Esse aumento pode ser o principal fator envolvido no 


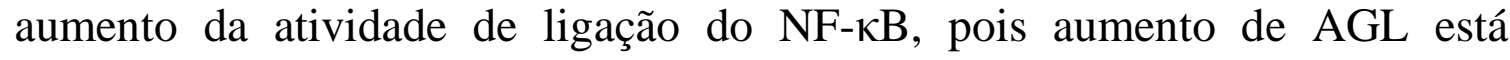
associado com ativação de IKK, que causa uma fosforilação e posterior

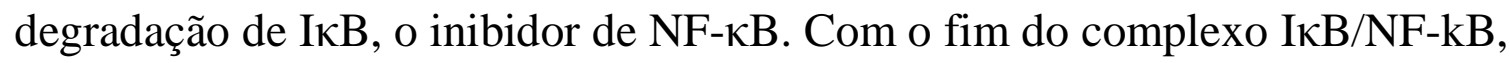
este fica livre para migrar para o núcleo da célula com subseqüente ligação em sítios específicos do DNA para regular a transcrição de um grande número de genes (ITANI et al., 2002).

Em pesquisa realizada com indivíduos normais submetidos à infusão de solução com sobrecarga de AGL verificou-se uma correlação entre aumento da concentração plasmática deste substrato e o aumento da degradação de IкB (o conteúdo de IкB reduziu 70\% após 6 horas), propiciando evidências de ativação da via IKK- $\beta / \mathrm{I} \kappa \mathrm{B} / \mathrm{NF}-\kappa \mathrm{B}$ (ITANI et al., 2002).

Finalizando essa parte da pesquisa, verificou-se que as alterações de expressão do mRNA afetaram o conteúdo protéico total de GLUT4, pois, de fato, ratos jejuados por 48 horas apresentaram uma diminuição no conteúdo protéico total de GLUT4 no músculo sóleo em relação aos ratos alimentados.

Estudos anteriores mostram resultados discordantes. Em CAMPS et al., 1992, um pool de sóleo, porção vermelha de gastrocnêmio e quadríceps, músculo cardíaco, tecido adiposo branco e tecido adiposo marrom de ratos jejuados por 48 horas apresentaram diminuição no conteúdo protéico total de GLUT4. Em KRAEGEN et al., 1993, o sóleo de ratos jejuados por 48 horas e 
em NEUFER, 1993 a porção vermelha do quadríceps de ratos jejuados por 72 horas não apresentaram alteração significativa no conteúdo protéico total de GLUT4. Em BOUREY et al., 1990, o sóleo de ratos jejuados por 72 horas apresentou aumento de 2,7x no conteúdo total de GLUT4. Os resultados controversos, observados no mesmo tipo de músculo, são de difícil interpretação, mas provavelmente envolvem diferenças metodológicas. Todos esses estudos foram publicados cerca de 15 anos atrás, quando a caracterização dos transportadores de glicose era recente, e o método de Western ainda não era rotineiro. Nesta época, os anticorpos ainda eram individualmente produzidos e a capacidade de reproduzir experimentos era menor.

A segunda parte desta pesquisa investigou se a insulina é capaz de alterar a expressão gênica de GLUT4. Para isso, foi utilizada a incubação do músculo sóleo in vitro em solução KHB acrescida ou não de insulina para verificar seus efeitos sem a interferência de outros fatores.

Para isto, inicialmente, investigamos se a incubação per se, induziria alguma modificação na expressão do GLUT4. Observou-se que a incubação por 70 minutos do músculo sóleo de ratos jejuados por 48 horas em solução KHB pura proporcionou um aumento na expressão do mRNA do GLUT4 e

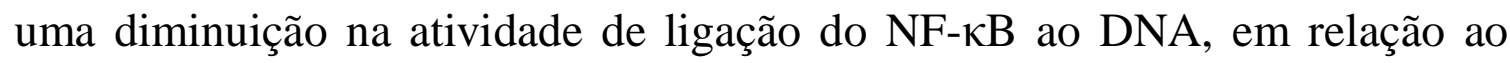


músculo sóleo de ratos jejuados. Estes resultados sugerem que o simples isolamento do músculo, apesar de preservada sua função in vitro, interrompeu a influência repressora do NF- $\kappa B$ sobre a expressão do GLUT4, que estava agindo in vivo e que poderia estar relacionada às alterações metabólicas, hormonais ou neurais do jejum, que já foram discutidas acima.

Além da participação do NF-אB na expressão do mRNA do GLUT4 induzido pela incubação apenas com KHB, um outro fator que pode ter influenciado nesse resultado é a proteína cinase ativada pelo 5'AMP (AMPK) um inibidor de NF-kB (CACICEDO et al, 2004). Na incubação do músculo em solução KHB sem substrato energético, mantendo-se o seu tônus contrátil, ocorre diminuição do ATP intracelular e aumento da relação AMP:ATP. Esse fator é conhecido como ativador da AMPK (HARDIE et al, 1997) e sua ativação está associada com o aumento da captação de glicose e da expressão do GLUT4 (FRYER et al., 2002).

Embora a incubação por 70 minutos do músculo sóleo de ratos jejuados por 48 horas em solução KHB tenha aumentado a expressão do mRNA do GLUT4, esse aumento não se refletiu em aumento significativo do conteúdo protéico total em relação ao músculo dos ratos jejuados. Esse resultado é extremamente interessante e certamente não decorre de tempo insuficiente (70 min) para aumentar a tradução da proteína, uma vez que na presença de 
insulina, o aumento da proteína foi detectado. Podemos assim propor que a incubação em KHB puro é suficiente para acionar mecanismos transcricionais que aumentam o mRNA, entretanto não é capaz de manter a maquinaria traducional agindo eficientemente. Este assunto será retomado adiante.

A incubação dos músculos por tempos crescentes induziu aumento progressivo no conteúdo do mRNA do GLUT4, sempre maior na presença de insulina. Conclui-se que há um efeito tempo-dependente da incubação aumentando a expressão do mRNA do GLUT4, o qual é exacerbado na presença de insulina. Esses resultados apontam para uma participação da insulina na estimulação da expressão gênica do GLUT4.

Verificou-se ainda que a incubação com insulina promoveu uma

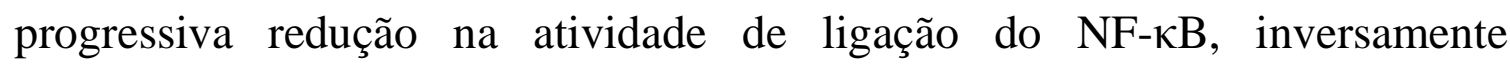
proporcional ao aumento do mRNA do GLUT4, deixando claro que o aumento da transcrição do GLUT4 envolveu a redução da atividade desse fator inibidor do GLUT4. Entretanto, curiosamente, observou-se que enquanto o aumento do mRNA do GLUT4 ao longo do tempo, na ausência de insulina, não se acompanhou de alteração do binding de NF- $\kappa B$, indicando que nesse efeito estimulador da transcrição observado na ausência de hormônio e de substrato glicose, outros fatores estimuladores da expressão do gene do GLUT4 devem ter sido acionados, provavelmente aqueles ativados por 
AMPK, cuja ativação depende da razão AMP:ATP, a qual deve estar aumentando ao longo do tempo.

A possibilidade de o NF- $\mathrm{BB}$ estar ativado in vivo, reprimindo o gene do GLUT4, já foi discutida acima. Porém, além disso, nossos resultados evidenciaram que a insulina, in vitro, inibiu a atividade do NF-кB. De fato, pesquisas anteriores já apontaram a inibição da atividade de ligação do NF- $\kappa B$ pela insulina tanto in vivo (DANDONA et al., 2001) como in vitro em células endoteliais (ALJADA et al., 2001). Além dessas, pesquisas em obesos tratados com tiazolinedionas (GHANIM et al., 2001, MOHANTY et al., 2004) e sulfoniluréias (SCHIEKOFER et al., 2003), que induzem aumento da sensibilidade à insulina, também revelam inibição de NF- $\kappa \mathrm{B}$ via aumento da

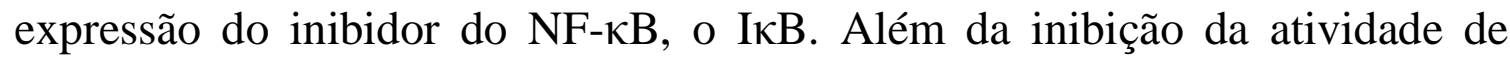

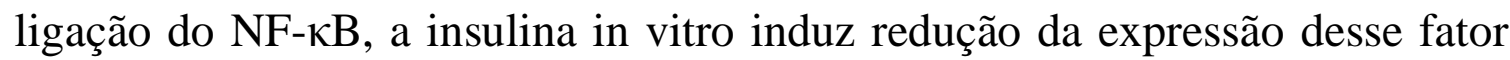
transcricional, fato este que já foi demonstrado em estudo do nosso laboratório (SILVA et al., 2005).

Essa modulação pela insulina é provavelmente provocada pelo aspecto anti-inflamatório da insulina sobre um dos principais mediadores de processos inflamatórios, o NF-אB (ALJADA et al., 2001). A insulina provoca um

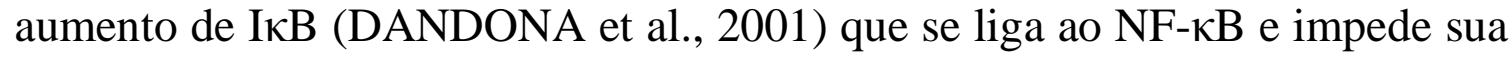
translocação para o núcleo. 
Uma importante questão que precisa ser discutida no presente estudo refere-se à presença de um "IRE" (Insulin Responsive Element) no promotor do gene do GLUT4. Este domínio foi funcionalmente caracterizado em estudos de deleção e corresponde a uma região de 27 bases localizada entre as bases -706 e -676 à montante da região codificadora do GLUT4 (COOKE \& LANE, 1998). Sua deleção impede a regulação do GLUT pela insulina, que, curiosamente, foi confirmada como sendo ação repressora do gene do GLUT4 (COOKE \& LANE, 1998). Mais do que isso, já foram caracterizados 2 fatores transcricionais que ao ligarem-se nesse domínio, em resposta à insulina, reprimem a trancrição do GLUT4, a saber o Nuclear Factor 1 (COOKE \& LANE, 1999) e o Olf-1/Early B cell factor (DOWELL \& COOKE, 2002).

Considerando-se o acima descrito, nossos resultados parecem contraditórios, entretanto, é importante destacar que: 1) os estudos de repressão do GLUT4 pela insulina via IRE foram realizados em células adiposas 3T3-L1 em cultura; 2) o efeito repressor da insulina foi observado em 8 (COOKE \& LANE, 1999) ou 24 (DOWELL \& COOKE, 2002) horas; e 3) sempre na presença de altas concentrações de glicose. Em conjunto, esses comentários indicam que, conforme mostrado no presente estudo, a insulina tem um efeito agudo, próprio, estimulador da transcrição do GLUT4; entretanto, ao longo do tempo e/ou na presença de glicose, o efeito da insulina 
pode ser repressor do GLUT4. De fato, in vivo, sabe-se que as situações de resistência à insulina, que cursam com hiperinsulinemia, geralmente acompanham-se de repressão da expressão do GLUT4 (MACHADO et al., 1993; MACHADO et al., 1994, PAPA, et al., 1997).

Finalmente, em relação as regulações de expressão do GLUT4 no presente estudo, observamos que houve um aumento do conteúdo de proteína em resposta ao tratamento com insulina, que se correlacionou positivamente com o aumento do mRNA e tende a ser progressivamente maior até $180 \mathrm{~min}$ de estudo. Interessantemente, esse aumento da proteína GLUT4 não foi observado quando os músculos eram incubados apenas com tampão, ressaltando a importância da insulina nesta resposta. Esta resposta na ausência de insulina, entretanto, foi diferente da observada no mRNA, que aumentou de maneira tempo-dependente. Em conjunto, esses dados indicam que, embora ao longo do tempo o conteúdo de mRNA do GLUT4 aumente na presença de tampão sem insulina, para que isto se reflita em aumento de proteína, é fundamental a presença de insulina, independentemente da presença de substrato glicose. Neste sentido, é preciso que se registre o importante papel que a insulina desempenha na atividade da maquinaria ribossomal de tradução. Sabe-se que a insulina, por meio de via que envolve a ativação da PI3K e posteriormente da mTOR, aumenta a atividade traducional em geral 
(BOLSTER et al., 2004). Particularmente em músculo, sabe-se que a insulina é fundamental para manter a síntese protéica, independentemente da quantidade de mRNA disponível (CROZIER et al., 2003).

Na literatura, a regulação da proteína GLUT4 também é conflitante. Tanto em células musculares L6 incubadas por 24 horas em solução com 100nM de insulina (KOIVISTO et al., 1991) como em adipócitos 3T3-L1 incubados por 36 horas em solução com $1 \mu \mathrm{M}$ de insulina (FLORESRIVEROS et al., 1993) houve diminuição no conteúdo protéico de GLUT4. Já a injeção de insulina ( $40 \mathrm{U} / \mathrm{kg}$ ) por 7 dias em ratos normais provocou um aumento de 2,4x no conteúdo total de GLUT4 no músculo sóleo (BOUREY et al.,1990). Essas diferentes respostas devem-se, provavelmente, a diferenças na concentração de insulina utilizada, no tempo de exposição das células ou tecido ao hormônio, e ainda na concentração de substratos (glicose principalmente) e outros hormônios que é variável principalmente quando comparamos estudos in vivo e in vitro. Além disso, esses estudos evidenciam o quanto a regulação da insulina sobre a expressão do gene do GLUT4 é complexa, merecendo sempre ser cuidadosa e detalhadamente avaliada. 


\section{CONCLUSÕES}

Com base nos resultados obtidos pode-se concluir que no músculo esquelético sóleo:

- $\mathrm{O}$ jejum de 48 horas proporcionou redução da expressão do mRNA do GLUT4, aumento da atividade de ligação do fator transcricional NF-אB ao DNA e diminuição no conteúdo protéico total de GLUT4;

- A incubação por 70 minutos em solução KHB pura reverteu as mudanças induzidas pelo jejum na expressão do mRNA do GLUT4

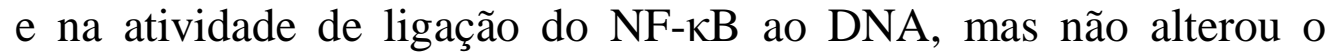
conteúdo protéico total de GLUT4;

- A incubação por 70 minutos em solução KHB adicionada de $16,7 \mathrm{nM}$ de insulina proporcionou, per se, aumento na expressão do mRNA de GLUT4, diminuição na atividade de ligação do NF-אB ao DNA e aumento do conteúdo protéico total de GLUT4;

- A incubação prolongada por 120 e 180 minutos em solução KHB adicionada de $16,7 \mathrm{nM}$ de insulina proporcionou um aumento na expressão do mRNA de GLUT4 de maneira tempo-dependente,

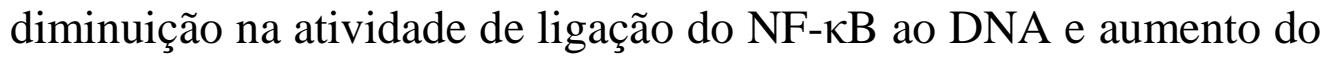
conteúdo protéico total de GLUT4. 
Resumindo, pode-se concluir que nas condições estudadas, fica evidente a regulação da expressão do GLUT4 in vivo pelo jejum e in vitro pela

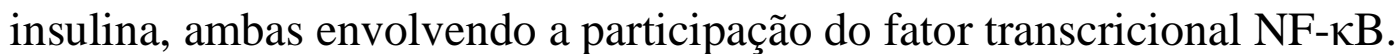




\section{REFERÊNCIA BIBLIOGRÁFICA}

- AlJADA, A., GARG, R., GUANIN, H., SAADEH, R., DANDONA, P. Insulin inhibits NF- $\mathrm{BB}$ and $\mathrm{MCP}-1$ expression in human aortic endothelial cells. J. Clin. Endocrinol. Metab. 86: 450-453, 2001.

- ANDREWS, N.C., FALLER, D. A rapid micropreparation technique for extraction of DNA-binding proteins from limiting numbers of mammalian cells. Nucleic Acids Res. 19, 24991, 1991.

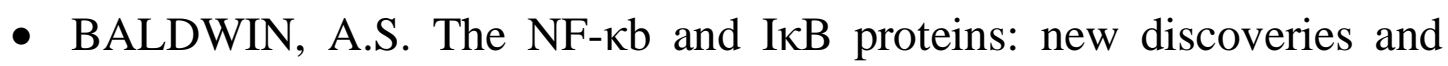
insights. Annu. Revi. Immunol. 14: 649-81, 1996.

- BLOCK, N.E., MENICK, D.R., ROBINSON, K.A., BUSE, M.G. Effect of denervation on the expression of two glucose transporter isoforms in rat hindlimb muscle. J Clin Invest. 88 (5): 1546-52, 1991.

- BOLSTER, D.R., JEFFERSON, L.S., KIMBALL, S.R. Regulation of protein synthesis associated with skeletal muscle hypertrophy by insulin-, amino acid- and exercise-induced signalling. Proc Nutr Soc. May;63(2):351-6, 2004.

- BOUREY, R.E., KORANYI, L., JAMES, D.E., MUECKLER, M., PERMUTT, M.A. Effects of altered glucose homeostasis on glucose transporter expression in skeletal muscle of the rat. J Clin Invest. 86:542-7, 1990. 
- BOWIE, A., O’NEILL, A.J. Oxidative stress and nuclear factor- $\kappa B$ activation. Biochem. Pharmacol. 59:13-23, 2000.

- CACICEDO, J.M., YAGIHASHI, N., KEANEY, J.F. Jr, RUDERMAN, N.B., IDO, Y. AMPK inhibits fatty acid-induced increases in NFkappaB transactivation in cultured human umbilical vein endothelial cells. Biochem Biophys res Commun. 26;324(4):1204-9, 2004.

- CAMPS, M., CASTElO, A., MUNOZ, P., MONFAR, M., TESTAR, X., PALACIN, M., ZORZANO, A. Effect of diabetes and fasting on GLUT4 (muscle/fat) glucose-transporter expression in insulin-sensitive tissues. Biochem J: 282, 765-772,1992.

- COOKE, D.W., LANE, M.D. A sequence element in the GLUT4 gene that mediates repression by insulin. J Biol Chem. Mar 13; 273(11):6210-7, 1998.

- COOKE, D.W., LANE, M.D. The transcription factor nuclear factor I mediates repression of the GLUT4 promoter by insulin. J Biol Chem. Apr 30;274(18):12917-24, 1999.

- CUERVO, A.M., HU, W., LIM, B., DICE, J.F. IкB is a substract for a selective pathway of lysosomal proteolysis. Mol. Biol. Cell. 9: 19952010, 1998. 
- CORTRIGHT, R.N., DONHM, G.L. Mechanism by which insulin and muscle contraction stimulate glucose transport. Can L Appl Physio. 22(6): 519-530, 1997.

- CROZIER, S.J., ANTHONY, J.C., SCHWORER, C.M., REITER, A.K., ANTHONY, T.G., KIMBALL, S.R. JEFFERSON, L.S. Tissuespecific regulation of protein synthesis by insulin and free fatty acids. Am J Physiol Endocrinol Metab. Oct;285(4):E754-62, 2003.

- DANDONA, P., AlJADA, A., MOHANTY, P., GUANIM, H., HAMOUDA, W., ASSIAN, E., AHMAD, S. Insulin inhibits intranuclear factor $\kappa \mathrm{B}$ and stimulates I $\kappa \mathrm{B}$ in mononuclear cells in obese subjects: evidence for an anti-inflamatory effect. J. Clin. Endocrinol. Metab. 86: 3257-3265, 2001.

- DOHM, G.L. Exercise effects on muscle insulin signaling and action. Invited Review: Regulation of skeletal muscle GLUT4 expression by exercise. J. Apl. Physiol. 93: 782-787, 2002.

- DOWELL, P., COOKE, D.W. Olf-1/early B cell factor is a regulator of glut4 gene expression in 3T3-L1 adipocytes. J Biol Chem. Jan 18;277(3):1712-8, 2002.

- EBERT, B.L., GLEADLE, J.M., O’ROURKE, J.F., BARTLETT, S.M., POULTON, J. RATCLIFFE, P.J. Isoenzime-specific regulation of genes involved in energy metabolism by hipoxia: similarities with the regulation of erythropoetin. Biochem J. 313: 809-814, 1996. 
- EVANS-STORMS, R.B., CIDLOWSKI, J.A. Delineation of an antiapoptotic action of glucocorticoids in hepatoma cells: the role of nuclear factor-kappa B. Endocrinology. 141(5):1854-1862, 2000.

- FLORES-RIVEROS, J.R., MCLENITHAN, J.C., EZAKI, O., LANE, M.D. Insulin down-regulates expression of the insulin-responsive glucose transporter (GLUT4) gene: Effects on transcription and mRNA turnover. Proc. Natl. Acad. Sci. USA. 90:512-516, 1993.

- FRYER, L.G., FOUfElle, F., BARNES, K., BALDWIN, S.A., WOODS, A., CARLING, D. Characterization of the role of the AMPactivated protein kinase in the stimulation of glucose transport in skeletal muscle cells. Biochem. J. 363, 167-174, 2002.

- GHANIM, H., GARG, R., ALJADA, A., MOHANTY, P., KUMBKARNI, Y., ASSIAN, E., HAMOUDA, W., DANDONA, P. Suppression of nuclear factor-kappaB and stimulation of inhibitor kappaB by troglitazone: evidence for an anti-inflammatory effect and a potential antiatherosclerotic effect in the obese. J Clin Endocrinol Metab. Mar;86(3):1306-12, 2001.

- GAO, J., REN, J., GULVE, E.A., HOLLOSZY, J.O. Additive effect of contractions and insulin on GLUT4 translocation into the sarcolemma. J Appl Physiol. 77:1597-1601, 1994. 
- GARFIN, D.E. One-dimensional gel electrophoresis. Methods Enzymol. 182:425-41, 1990.

- GARVEY, W.T., HUECKSTEADT, T.P., BIRNBAUM, M.J. Pretranslational supression of an insulin-responsive glucose transporter in rats with diabetes mellitus. Science. 245(4913):60-3, 1989.

- GASTER, M; POULSEN, P; HANDBERG, A; SCHRODER, H.D.; BECKNIELSEN, H. Direct evidence of fiber type-dependent GLUT4 expression in human skeletal muscle. Am J Physiol. 278: E910-E916, 2000.

- GOODYEAR, L.J., CHANG, P.Y., SHERWOOD, D.J., DUFRESNE, S.D., MOLLER, D.E. Effects of exercise and insulin on mitogenactivated protein kinase signaling pathways in rat skeletal muscle. Am J Physiol Endocrinol Metab. 271: E403-E408, 1996.

- GOULD, G.W., HOLMAN, G.D. The glucose transporter family: structure, function and tissue-specific expression. Biochem J. 295:329341, 1993.

- GRAY, S., FEINBERG, M.W., HULL, S., KUO, C.T., WATANABE, M., SENBANERJEE, S., DEPINA, A., HASPEL, R., JAIN, M.K. The Krüppel-like factor KLF15 regulates the insulin-sensitive glucose transporter GLUT4. J. Biol. Chem. 277(37): 34322-34328, 2002. 
- HARDIE, D.G., CARLING, D. The AMP-activated protein kinase: fuel gauge of the mammalian cell? Eur. J. Biochem. 246:259-273, 1997.

- HILL, C.S., TREISMAN, R. Transcriptional regulation by extra-celular signals: mechanisms and specificity. Cell. 80: 199-211, 1995.

- ITANI, S.I., RUDERMAN, N.B., SCHMIEDER, F., BODEN, G. Lipidinduced insulin resistance in human muscle is associated with changes in diacylglycerol, protein kinase C, and IкB- $\alpha$. Diabetes 51: 2005-2011, 2002.

- JOOST, H.G., THORENS, B. The extended GLUT-family of sugar/polyol transport facilitators: nomenclature, sequence characteristics, and potential function of its novel members. Mol Membr Biol. 18(4):247-56, 2001.

- KOIVISTO, U.M., MARTINEZ-VALDEZ, H., BILAN, P.J., BURDETT, E., RAMLAL, T., KLIP, A. Differential regulation of the GLUT1 and GLUT4 glucose transport systems by glucose and insulin in L6 muscle cells in culture. J. Biol. Chem. 266:2615-2621, 1991.

- KRAEGEN, E.W., SOWDEN, J.A., HALSTEAD, M.B., CLARK, P.W., RODNICK, K.J., CHISHOLM, D.J., JAMES, D.E. Glucose transporters and in vivo glucose uptake in skeletal and cardiac muscle: fasting, insulin stimulation and immunoisolation studies of GLUT1 and GLUT4. Biochem J. 295 :287-293, 1993. 
- KUMAR, A., TAKADA, Y., BORIEK, A.M., AGGARWAL, B.B. Nuclear factor-kappaB: its role in health and disease. J Mol Med. Jul;82(7):434-48, 2004.

- LI, Q., VERMA, I. M. NF-кB regulation in the immune system. Nat Rev Immunol. Dec;2(12):975, 2002.

- LOWRY, O.H., ROSEBROUGH, N.J., FARR, A.L., RANDALL, R.J. Protein measurement with the Folin phenol reagent. J Biol Chem. Nov;193(1):265-75, 1951.

- MACHADO, U.F., SCHAAN, B.D., SERAPHIM, P.M. Transportadores de glicose na síndrome metabólica. Arq. Bras. Endocrinol. Metab. 50(2): 177-189, 2006.

- MACHADO, U.F., SHIMIZU, Y., SAITO, M. Decreased glucose transporter (GLUT 4) content in insulin-sensitive tissues of obese aurothioglucose- and monosodium glutamate-treated mice. Horm Metab Res. Sep;25(9):462-5, 1993.

- MACHADO, U.F., SHIMIZU, Y., SAITO, M. Reduced content and preserved translocation of glucose transporter (GLUT 4) in white adipose tissue of obese mice. Physiol Behav. Apr;55(4):621-5, 1994. 
- MacLEAN, P.S.; ZHENG, D.; DOHM, G.L. Muscle glucose transponder (GLUT4) gene expression during exercise. Exerc Sport Sci, 28(4): 148-152, 2000.

- MOHANTY, P., ALJADA, A., GHANIM, H., HOFMEYER, D., TRIPATHY, D., SYED, T., AL-HADDAD, W., DHINDSA, S., DANDONA, P. Evidence for a potent antiinflammatory effect of rosiglitazone. J. Clin. Endocrinol. Metab. 89(6):2728-35, 2004.

- MORA, S., PESSIN, J.E. The MEF2A isoform is required for striated muscle-specific expression of the insulin-responsive GLUT4 glucose transporter. J Biol Chem. 273:14285-14292, 2000.

- NEEL, J.V. Diabetes mellitus: a "thrifty" genotype rendered detrimental by progress? Am J Hum Genet 14:353-362,1962.

- NEUFER, P.D., CAREY, J.O., DOHM, G.L. Transcriptional regulation of the gene for glucose transporter GLUT4 in skeletal muscle. J Biol Chem. 268(19):13824-13829, 1999.

- NORTON, L., PARR, T., BARDSLEY, R.G., YE, H., TSINTZAS, K. Characterization of GLUT4 and calpain expression in healthy human skeletal muscle during fasting and refeeding. Acta Physiol Mar;189(3):233-40, 2007. 
- OJUKA, E.O., JONES, T.E., NOLTE, L.A., CHEN, M., WAMHOFF, B.R., STUREK, M., HOLLOSZY, J.O. Regulation of GLUT4 biogenesis in muscle: evidence for involvement of AMPK and $\mathrm{Ca}^{2+}$. Am J Physiol Endocrinol Metab. 282: E1008-E1013, 2002.

- OKAMOTO, M.M.; SUMIDA, D.H.; CARVALHO, C.R.; VARGAS, A.M.; HEIMANN, J.C.; SCHAAN, B.D.; MACHADO, U.F. Changes in dietary sodium comsumption modulate GLUT4 gene expression and early steps of insulin signaling. Am J Physiol Regul Integr Comp Physiol. 286(4): R779-85, 2004.

- PAPA, P.C., SERAPHIM, P.M., MACHADO, U.F. Loss of weight restores GLUT 4 content in insulin-sensitive tissues of monosodium glutamate-treated obese mice. Int J Obes Relat Metab Disord. Nov;21(11):1065-70, 1997.

- PlOUG, T., STALlKNECHT, B.M., PEDERSEN, O., KAHN, B.B., OHKUWA, T., VINTEN, J., GALBO, H., Effect of endurance training on glucose transport capacity and glucose transporter expression in rat skeletal muscle. Am J Physiol. 259:778-786, 1990.

- PlOUG, T., VAN DEURS, B., AL, H., CUSHMAN, S.W., RALSTON, E., Analysis of GLUT4 distribuition in whole skeletal muscle fibers: identification of distinct storage compartments that are recruited by insulin and muscle contraction. J Cell Biol 135:415-430, 1998. 
- ROYER, C., LACHUER, J., CROUZOUlON, G., POUX, J., PEYRONNET, J., MAMET, J., PEQUIGNOT, J., DALMAZ, Y. Effects of gestational hypoxia on mRNA levels of GLUT3 and GLUT4 transporters, hypoxia inducible factor-1 and thyroid receptors in developing rat brain. Brain Research. 856: 119-128, 2000.

- RUAN, H; HACOHEN, N., GOLUB, T.R., Tumor necrosis factor supress adipocyte-especific genes and activates expression of preadipocyte genes in 3T3-L1 adipocytes. NF- $\kappa B$ activation by TNF- $\alpha$ is obligatory. Diabetes. 51 1319-1336, 2002.

- SANTAluCia, T., MORENO, H., PALACIN, M., YACOUB, M.H., BRAND, N.J., ZORZANO, A. A novel functional co-operation betwenn MyoD, MEF2 and TR $\alpha 1$ is sufficient for the induction of GLUT4 gene expression. J. Mol. Biol. 314: 195-204, 2001.

- SATO, Y.; OSHIDA, Y.; OHSAWA, I. The role of glucose transport in the regulation of glucose utilization by muscle. In: MAUGHAN, R.J. \& SHIRREFFS, S.M. Biochemistry of exercise IX. Human Kinetics, (p.37-50), 1996.

- SCHEEPERS, A., JOOST, H.G., SCHÜRMANN, A. The glucose transporter families SGLT and GLUT: molecular basis of normal and aberrant function. J Parent. Ent. Nutrit. 28(5): 365-372, 2004. 
- SCHIEKOFER, S., RUDOFSKY, G.J., ANDRASSY, M., SCHNEIDER, J., ISERMANN, B., KANITZ, M., ELSENHANS, S., HEINLE, H., BALLETSHOFER, B., HARING, H.U., SCHLEICHER, E., NAWROTH, P.P., BIERHAUS, A. Glimepiride reduces mononuclear activation of the redox-sensitive transcription factor nuclear factor-kappa B. Diabetes Obes Metab. Jul;5(4):251-61, 2003.

- Shimaya, A., KUROSAKI, E., SHIOKUDA, K., NAKANO, R., SHIBASAKI, M., SHIKAMA, H. YM268 increases the glucose uptake, cell differentiation and mRNA expression of glucose transporter in 3T3L1 adipocytes. Horm. Metab. Res. 30(9): 543-548, 1998.

- SilVA, J.L., GIANNOCCO, G., FURUYA, D.T., LIMA, G.A., MORAES, P.A., NACHEF, S., BORDIN, S., BRITTO, L.R., NUNES, M.T., MACHADO, U.F. NF- $\kappa B$, MEF2A, HIF1-a involviment on insulin- and contraction-induced regulation of GLUT4 gene expression in soleus muscle. Mol. Cell Endocrinol. 240(1-2):82-93, 2005.

- TOWBIN, H., STAEHELIN, T., GORDON, J. Electrophoretic transfer of proteins from polyacrylamide gels to nitrocellulose sheets: procedure and some applications. Proc Natl Acad Sci U S A. Sep;76(9):4350-4, 1979.

- WATSON, R.T., KANZAKI, M., PESSIN, J.E. Regulated membrane trafficking of the insulin-responsive glucose transporter 4 in adipocytes. Endoc. Reviews 25:177-204, 2004. 
- WEINSTEIN, S.P., WATTS, J., HABER, R.S., Thyroid hormone increases muscle/fat glucose transport gene expression in rat skeletal muscle. Endocrinology. 129(1):455-464, 1991.

- ZANQUETTA, M.M., NASCIMENTO, M.E., MORI, R.C., D’AGORD S.B., YOUNG, M.E., MACHADO, U.F. Participation of betaadrenergic activity in modulation of GLUT4 expression during fasting and refeeding in rats. Metabolism. Nov;55(11):1538-45, 2006.

- ZORZANO, A., FANDOS, C., PALIACIN, M. Role of plasma membrane transporters in muscle metabolism. Biochem. J. 349: 667$688,2000$.

- ZORZANO, A., PALACIN, M., GUMA, A. Mechanism regulating GLUT4 glucose transporter expression and glucose transport in skeletal muscle. Acta Physiol Scan 183:43-58, 2005. 